\title{
Improved simulation of isoprene oxidation chemistry with the ECHAM5/MESSy chemistry-climate model: lessons from the GABRIEL airborne field campaign
}

\author{
T. M. Butler, D. Taraborrelli, C. Brühl, H. Fischer, H. Harder, M. Martinez, J. Williams, M. G. Lawrence, and \\ J. Lelieveld
}

Max Planck Institute for Chemistry, Mainz, Germany

Received: 19 February 2008 - Published in Atmos. Chem. Phys. Discuss.: 27 March 2008

Revised: 4 July 2008 - Accepted: 10 July 2008 - Published: 5 August 2008

\begin{abstract}
The GABRIEL airborne field measurement campaign, conducted over the Guyanas in October 2005, produced measurements of hydroxyl radical $(\mathrm{OH})$ concentration which are significantly higher than can be simulated using current generation models of atmospheric chemistry. Based

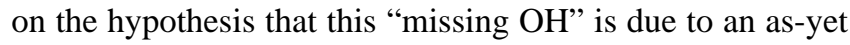
undiscovered mechanism for recycling $\mathrm{OH}$ during the oxidation chain of isoprene, we determine that an $\mathrm{OH}$ recycling of about $40-50 \%$ (compared with $5-10 \%$ in current generation isoprene oxidation mechanisms) is necessary in order for our modelled $\mathrm{OH}$ to approach the lower error bounds of the $\mathrm{OH}$ observed during GABRIEL. Such a large amount of $\mathrm{OH}$ in our model leads to unrealistically low mixing ratios of isoprene. In order for our modelled isoprene mixing ratios to match those observed during the campaign, we also require that the effective rate constant for the reaction of isoprene with $\mathrm{OH}$ be reduced by about 50\% compared with the lower bound of the range recommended by IUPAC. We show that a reasonable explanation for this lower effective rate constant could be the segregation of isoprene and $\mathrm{OH}$ in the mixed layer. Our modelling results are consistent with a global, annual isoprene source of about $500 \mathrm{Tg}(\mathrm{C}) \mathrm{yr}^{-1}$, allowing experimentally derived and established isoprene flux rates to be reconciled with global models.
\end{abstract}

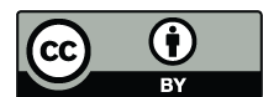

Correspondence to: T. M. Butler (tmb@mpch-mainz.mpg.de)

\section{Introduction}

During the GABRIEL airborne field campaign, conducted over the Guyanas in October 2005, concentrations of $\mathrm{OH}$ were measured in excess of those which can be reproduced by models of atmospheric chemistry based on current understanding (Lelieveld et al., 2008, and other papers in this issue). In this study we present detailed comparisons of the measurements taken during GABRIEL with the ECHAM5/MESSy AC-GCM (Atmospheric Chemistry General Circulation Model), and attempt to reconcile our simulations with the measurements.

$\mathrm{OH}$ plays an important role in the chemistry of the troposphere, being the oxidising species primarily responsible for the removal of reactive pollutants (e.g. Lelieveld et al., 2004). It is possible to estimate global average OH concentrations using observed distributions of $\mathrm{OH}$ precursors (e.g. Spivakovsky et al., 1990, 2000) or compounds in the atmosphere which are removed by reaction with $\mathrm{OH}$, most notably methyl chloroform (e.g. Krol and Lelieveld, 2003; Prinn et al., 2005). $\mathrm{OH}$ at regional scales can also be calculated by examining the relative variability of compounds which are removed by $\mathrm{OH}$ (e.g. Williams et al., 2001; Bartenbach et al., 2007). Direct measurements of $\mathrm{OH}$ in the troposphere are also possible using a variety of techniques (e.g. Heard and Pilling, 2003, and references therein).

$\mathrm{OH}$ concentrations measured in polluted urban environments are often lower than predicted by models (e.g. George et al., 1999; Shirley et al., 2006). Such urban environments are characterised by high anthropogenic emissions of non methane hydrocarbons (NMHC) and oxides of nitrogen $\left(\mathrm{NO}_{\mathrm{x}}, \mathrm{NO}+\mathrm{NO}_{2}\right.$, with mixing ratios of the order of several

Published by Copernicus Publications on behalf of the European Geosciences Union. 
$\mathrm{nmol} \mathrm{mol}^{-1}$ ). The oxidation of these anthropogenic NMHC by $\mathrm{OH}$ radicals leads to production of the $\mathrm{HO}_{2}$ radical, which reacts with $\mathrm{NO}$ to recycle $\mathrm{OH}$ and form $\mathrm{NO}_{2}$, which then photolyses to form ozone $\left(\mathrm{O}_{3}\right.$, photolysis of which is responsible for the primary production of $\mathrm{OH}$ when the resulting excited $\mathrm{O}\left({ }^{1} \mathrm{D}\right)$ atoms react with water vapour). The net result of urban photochemistry is maintenance of high $\mathrm{OH}$ concentrations during removal of $\mathrm{NMHC}$ and production of $\mathrm{O}_{3}$.

Away from the influence of anthropogenic emissions, the atmospheric chemistry of $\mathrm{OH}$-initiated oxidation is quite different. $\mathrm{NO}_{\mathrm{x}}$ is typically three to four orders of magnitude less abundant, and NMHC, when present, are usually of biogenic origin. The most abundant biogenic NMHC globally is isoprene (Guenther et al., 2006). Tan et al. (2001) and Carslaw et al. (2001) both report field measurements of $\mathrm{OH}$ in regions of low $\mathrm{NO}_{\mathrm{x}}\left(<100 \mathrm{pmol} \mathrm{mol}^{-1}\right)$ in the presence of isoprene mixing ratios in excess of $1 \mathrm{nmol} \mathrm{mol}^{-1}$. In both cases the measured $\mathrm{OH}$ concentrations are higher than those predicted by models. Thornton et al. (2002) have also noted inconsistencies in the modelled $\mathrm{HO}_{\mathrm{x}}\left(\mathrm{OH}+\mathrm{HO}_{2}\right)$ budget in $\mathrm{NO}_{\mathrm{x}}$-poor environments in the presence of isoprene. Tan et al. (2001) speculated that ozonolysis of terpenes may be a source of this "missing OH", however Carslaw et al. (2001) measured a comprehensive set of biogenic NMHC, and included their ozonolysis in their model, which was not enough to increase their modelled $\mathrm{OH}$ to be in line with the measurements. Ren et al. (2006) also measured $\mathrm{OH}$ in a relatively low $\mathrm{NO}_{\mathrm{x}}\left(\approx 100 \mathrm{pmol} \mathrm{mol}^{-1}\right)$ forested area and were able to reproduce their observed $\mathrm{OH}$ quite well with a model. In contrast to the studies reported by Tan et al. (2001) and Carslaw et al. (2001), Ren et al. (2006) report low mixing ratios of isoprene (of the order of $100 \mathrm{pmol} \mathrm{mol}^{-1}$ ) which accounted for an unusually low fraction of the total $\mathrm{OH}$ reactivity $(\approx 15 \%)$. Kuhn et al. (2007) and Karl et al. (2007), measuring surface fluxes and mixing ratios of isoprene over Amazonia, also infer concentrations of $\mathrm{OH}$ radicals in the presence of isoprene which are higher than calculated from chemical box models.

This tendency of isoprene to deplete the $\mathrm{OH}$ concentration in regions of low $\mathrm{NO}_{\mathrm{x}}$, especially over tropical continental regions (most notably the Amazon), and thus to lead to higher mixing ratios of isoprene than are measured has also been noted in global three dimensional models of atmospheric chemistry (e.g. Houweling et al., 1998; von Kuhlmann et al., 2003; Folberth et al., 2006; Jöckel et al., 2006). A common solution in global atmospheric chemistry models has been to reduce the flux of isoprene by about one half (e.g. Pozzer et al., 2007). This leads to an inconsistency between isoprene flux estimates based on a multitude of laboratory and field observations (Guenther et al., 1995, 2006) and many of the current state of the art atmospheric chemistry models.

In this paper we examine the hypothesis that the missing $\mathrm{OH}$ in $\mathrm{NO}_{\mathrm{x}}$-poor, isoprene-rich environments is due to a yet undiscovered $\mathrm{OH}$ recycling mechanism present in the isoprene oxidation chain, as proposed by Lelieveld et al. (2008).
We present the results of simulations performed with a global three dimensional AC-GCM using a number of different isoprene oxidation mechanisms, including several with differing degrees of imposed $\mathrm{OH}$ regeneration, and compare these with measurements taken during the GABRIEL campaign in order to estimate the degree of $\mathrm{OH}$ recycling required for our model to agree with the GABRIEL measurements.

Section 2 describes our methodology, including our modelling approach, in Sect. 3 we compare the results of our model runs with the GABRIEL measurements before examining the global implications in Sect. 4, and we conclude with Sect. 5 .

\section{Methodology}

We use the ECHAM5/MESSy global three dimensional ACGCM. This model has been developed and evaluated by Jöckel et al. (2006). The chemical submodel, MECCA (Sander et al., 2005), used in this evaluation includes a treatment of isoprene oxidation known as the Mainz Isoprene Mechanism (MIM) which was originally developed by Pöschl et al. (2000) and modified by von Kuhlmann et al. (2004). For this study we select only reactions relevant to the troposphere, and we omit halogen chemistry. Throughout the text we refer to this chemical mechanism as the "MIMvK" mechanism. The other submodels used in this study are CONVECT (Tost et al., 2006a), EMDEP (Ganzeveld et al., 2006), LNOX (Tost et al., 2007), OFFLEM (Kerkweg et al., 2006), SCAV (Tost et al., 2006b), TNUDGE (Kerkweg et al., 2006), as well as CLOUD, CVTRANS, JVAL, RAD4ALL, and TROPOP (Jöckel et al., 2006). We use offline emissions from the OFFLEM submodel, and online emissions and dry deposition from the EMDEP submodel. Turbulent vertical transport and boundary layer mixing processes are treated using an eddy diffusion method (Roeckner et al., 2003). The online photolysis module JVAL contains additionally to the reactions given in Jöckel et al. (2006) the photolysis of MVK, MACR, glyoxal and glycolaldehyde based on Sander et al. (2006). We run the model at T42 horizontal resolution (about $2.8 \times 2.8$ degrees), and with 31 levels up to $10 \mathrm{hPa}$ in the vertical, in "free running" mode, forced only by AMIP sea surface temperatures, with no additional nudging of the model meteorology. In order to study the effects of changes in the chemical mechanism in a consistent way, we have turned off all feedbacks in the model between our simulated trace gases. and the climate model. This ensures that all of our model runs are performed with identical meteorology, and that our comparisons only examine the effect of our changes to the chemical mechanism.

Figure 1 shows the grid of ECHAM5/MESSy superimposed over the region of the GABRIEL airborne campaign along with the tracks of the flights. These flights were performed between 5 October and 15 October 2005, with measurements taken between the hours of 10:30 and 20:00 UTC 


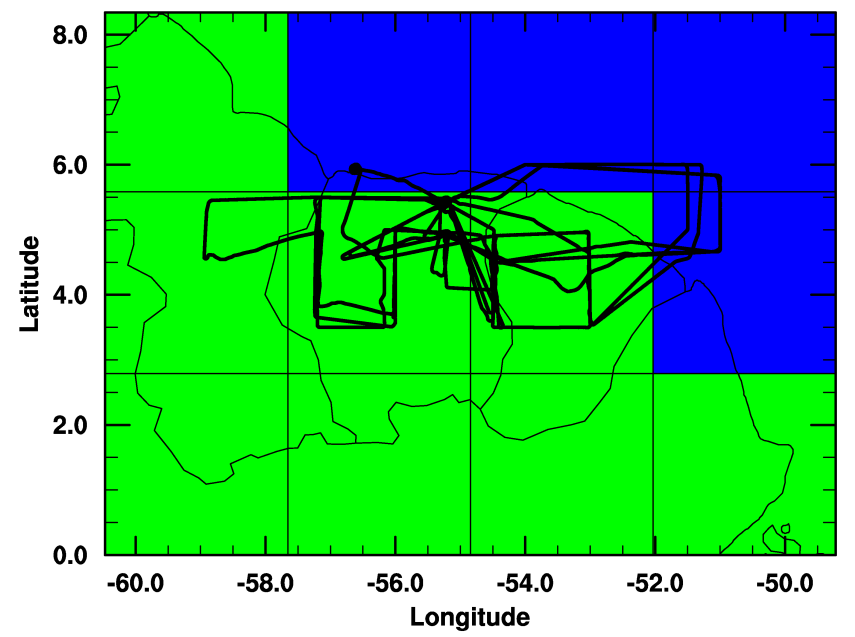

Fig. 1. The Guyanas in ECHAM5/MESSy. Land grid cells are shown in green, and ocean gridcells in blue. GABRIEL flights are shown as solid black lines.

(07:30 and 17:00 local time), from ground level up to an altitude of $11 \mathrm{~km}$. The aircraft was a Learjet $35 \mathrm{~A}$ belonging to the Gesellschaft für Flugzieldarstellung (GFD, Hohn, Germany), and was based at Zanderij International Airport for the duration of the GABRIEL campaign. Most of the data collected during the campaign correspond with the model grid cell directly over Suriname, and the cell immediately to the east. Isoprene was measured with an onboard PTR-MS system (Proton Transfer Reaction Mass Spectrometer, Eerdekens et al., 2008), while $\mathrm{OH}$ and $\mathrm{HO}_{2}$ were measured with a wing-mounted LIF instrument (Laser Induced Fluorescence, Martinez et al., 2008). Chemical weather forecasting support for the campaign was provided using the MATCH-MPIC (Model of Atmospheric Transport and CHemistry, Max Planck Institute for Chemistry version) forecasting system (Lawrence et al., 2003). A more general description of the campaign is provided by Lelieveld et al. (2008), and Stickler et al. (2007) includes further details of other species measured during the campaign.

As we perform a large number of simulations, the results of which we only wish to compare with the measurements taken during the GABRIEL campaign in October 2005, we initialise the model with tracer fields from the evaluation S1 simulation (Jöckel et al., 2006), allow the model two months (August and September 2005) to spinup, and then average the results for October 2005. We use an output frequency of $5 \mathrm{~h}$, and our averaging method preserves the diurnal variability of the model output. For comparison with the GABRIEL measurements in Sect. 3, we perform virtual flythroughs of our model by interpolating our model output spatially and temporally along the flight paths shown in Fig. 1. When presenting the global implications of our modified chemical mechanisms in Sect. 4, we allow three months of spinup time (October, November and December 2004) and present annual averages for 2005 .

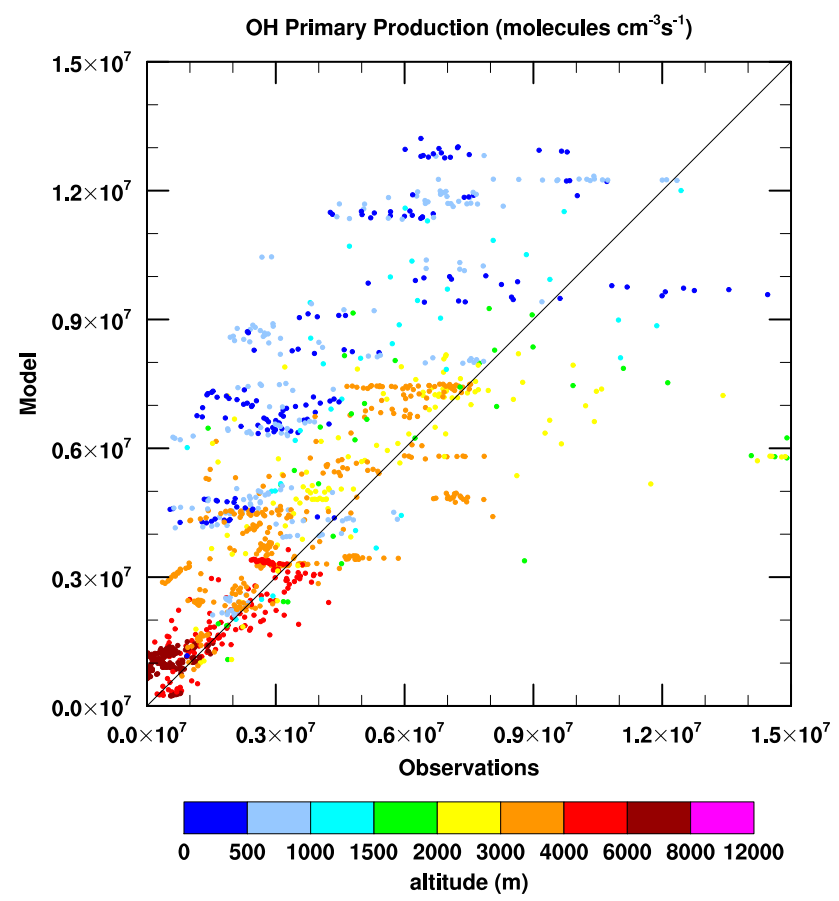

Fig. 2. Primary $\mathrm{OH}$ radical production as simulated by ECHAM5/MESSy, compared with GABRIEL measurements.

\section{Results}

Figure 2 shows the comparison between model and measurements of the primary production of $\mathrm{OH}$ radicals due to photolysis of $\mathrm{O}_{3}$ followed by reaction of the resulting excited $\mathrm{O}\left({ }^{1} \mathrm{D}\right)$ atoms with $\mathrm{H}_{2} \mathrm{O}$. We plot the values based on the measurements taken during all GABRIEL flights on the $\mathrm{x}$-axis, and each corresponding point from the virtual flythrough of our model output on the y-axis. The modelmeasurement comparison for the individual terms involved in the calculation of $\mathrm{OH}$ primary production (mixing ratios of $\mathrm{O}_{3}$, the photolysis frequency $\mathrm{O}_{3} \rightarrow \mathrm{O}\left({ }^{1} \mathrm{D}\right)$, and mixing ratios of $\mathrm{H}_{2} \mathrm{O}$ ) are shown along with the model/measurement comparison for mixing ratios of $\mathrm{NO}$ in Fig. 1 of the Electronic Supplement http://www.atmos-chem-phys.net/8/4529/2008/ acp-8-4529-2008-supplement.pdf to this article. Our model reproduces the photolysis rate of $\mathrm{O}_{3}$ fairly well, and slightly underestimates the observed mixing ratio of $\mathrm{H}_{2} \mathrm{O}$ at lower altitudes. Our overestimation of $\mathrm{OH}$ primary production at low altitudes compared with the GABRIEL measurements (Fig. 2) is due to our overestimation of $\mathrm{O}_{3}$ mixing ratios at low altitudes. Observations of $\mathrm{NO}$, important for $\mathrm{OH}$ recycling (Sect. 1), are characterised by mostly quite low mixing ratios $\left(0-50 \mathrm{pmol} \mathrm{mol}^{-1}\right)$ and occasionally by intense plumes, which are associated with emissions from ships in the Atlantic Ocean to the east of French Guyana and localised anthropogenic activity over the Guyanas. The highest simulated NO mixing ratios over the GABRIEL domain are due 
a)

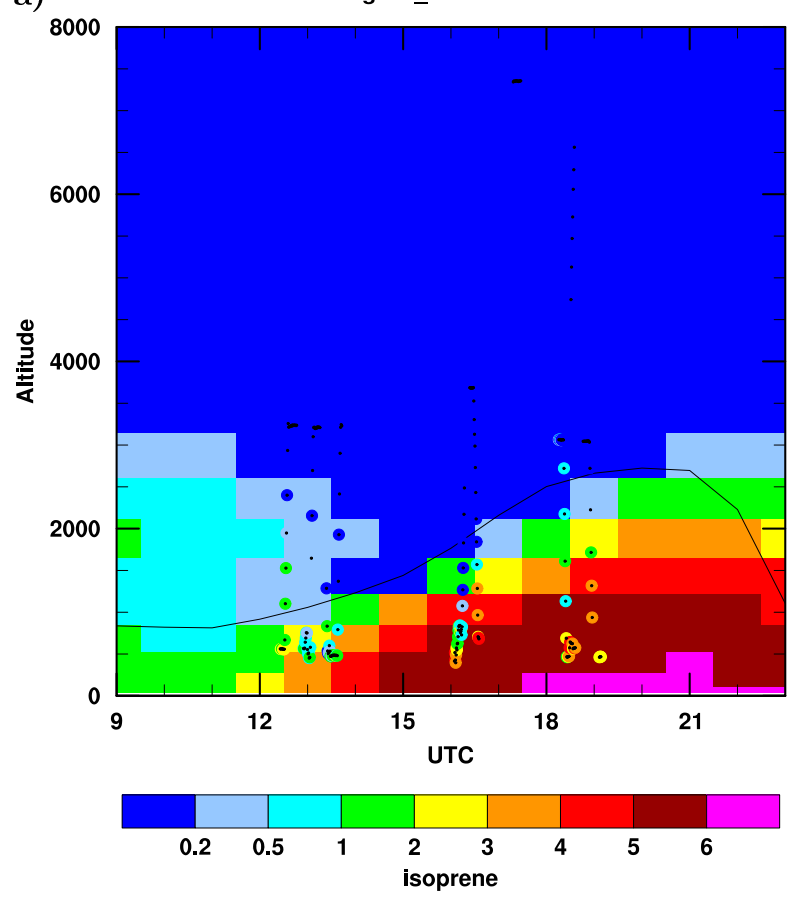

b)
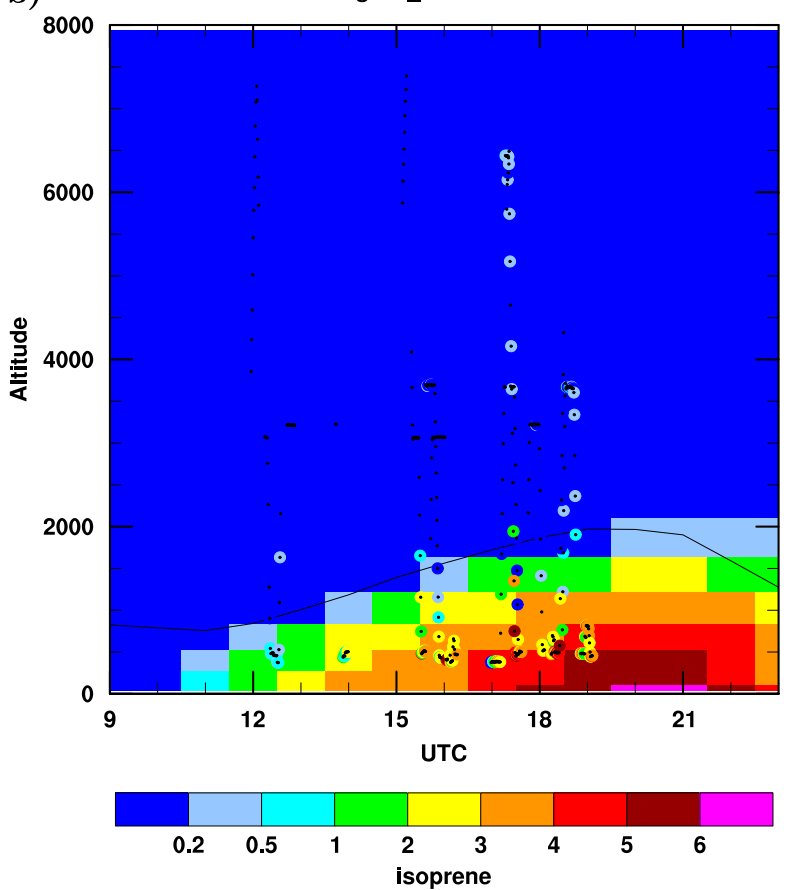

Fig. 3. GABRIEL isoprene measurements (coloured points) superimposed on the modelled diurnal evolution of the October average isoprene mixing ratios from the $\mathrm{MIMvK}$ model run $\left(\mathrm{nmol} \mathrm{mol}^{-1}\right)$, along with the model diagnosed mixed layer height (solid line) for the grid cell corresponding with (a) Suriname and (b) French Guyana.

to ship emissions. Observed NO mixing ratios over land are generally only slightly overestimated by the model.

Isoprene is also an important term in the $\mathrm{OH}$ budget over tropical forests, being potentially one of the largest sinks. The vertical profile, including the diurnal variability of isoprene from the model run performed with the MIMvK chemical mechanism is shown in Fig. 3, which also shows the diurnal evolution of the diagnosed height of the mixed layer from our model (solid line) and the GABRIEL isoprene measurements (coloured points). While this model run has too much isoprene in comparison with the measurements, it seems that model does well in simulating the vertical extent of isoprene mixing over both Suriname and French Guyana. Our model calculates the flux of isoprene to the atmosphere online using the algorithm of Guenther et al. (1995), with a global annual flux of isoprene of about $500 \mathrm{Tg}(\mathrm{C})$. Over the Suriname grid cell, this corresponds to an integrated daily flux of $70 \mathrm{mg}$ (isoprene) $/ \mathrm{m}^{2} / \mathrm{d}$, which peaks at $9.4 \mathrm{mg}$ (isoprene) $/ \mathrm{m}^{2} / \mathrm{h}$ around midday. The isoprene flux over the Guyanas during the GABRIEL campaign has been estimated at about $8 \mathrm{mg}$ (isoprene) $/ \mathrm{m}^{2} / \mathrm{h}$ (Eerdekens et al., 2008).

Figure 4 shows the comparison between the measurements of $\mathrm{OH}$ and isoprene, and the corresponding points from the virtual flythrough of the MIMvK model run. The model overestimation of isoprene mixing ratios, seen previously in Fig. 3, and typical for global model simulations of this region
(Sect. 1) is again visible in Fig. 4. OH concentrations in the model mixed layer are severely underestimated despite our overestimation of the $\mathrm{OH}$ primary production rate (Fig. 2).

In Fig. 2 of the Electronic Supplement http://www.atmos-chem-phys.net/8/4529/2008/

acp-8-4529-2008-supplement.pdf to this paper, we also show similar comparisons for other species measured during the GABRIEL campaign $\left(\mathrm{HO}_{2}, \mathrm{OH} / \mathrm{HO}_{2}\right.$ ratio, total organic peroxides, the sum of MACR and MVK (methacrolein and methyl vinyl ketone), $\mathrm{CH}_{3} \mathrm{CHO}$ (acetaldehyde) and HCHO (formaldehyde). The model clearly has difficulty in simulating the observed measurements of both $\mathrm{OH}$ and $\mathrm{HO}_{2}$ in the mixed layer. The small number of points in Fig. 4 for which good model-measurement agreement is observed correspond with measurements taken over the ocean to the East of French Guyana, where no isoprene is present. Not only are the concentrations of both $\mathrm{OH}$ and $\mathrm{HO}_{2}$ severely underestimated, but the $\mathrm{HO}_{2} / \mathrm{OH}$ ratio is also not reproduced. Similar problems are also seen in chemical weather forecast output ${ }^{1}$ from the MATCH-MPIC forecasting system. The simulated mixing ratios of the sum of MACR and MVK, both intermediate products of isoprene oxidation which are themselves oxidised by $\mathrm{OH}$, are too high in comparison with the measurements. This is most

$1_{\text {available via the world wide web at: }}$ we
http://www.mpch-mainz.mpg.de/ lawrence/forecasts.html.



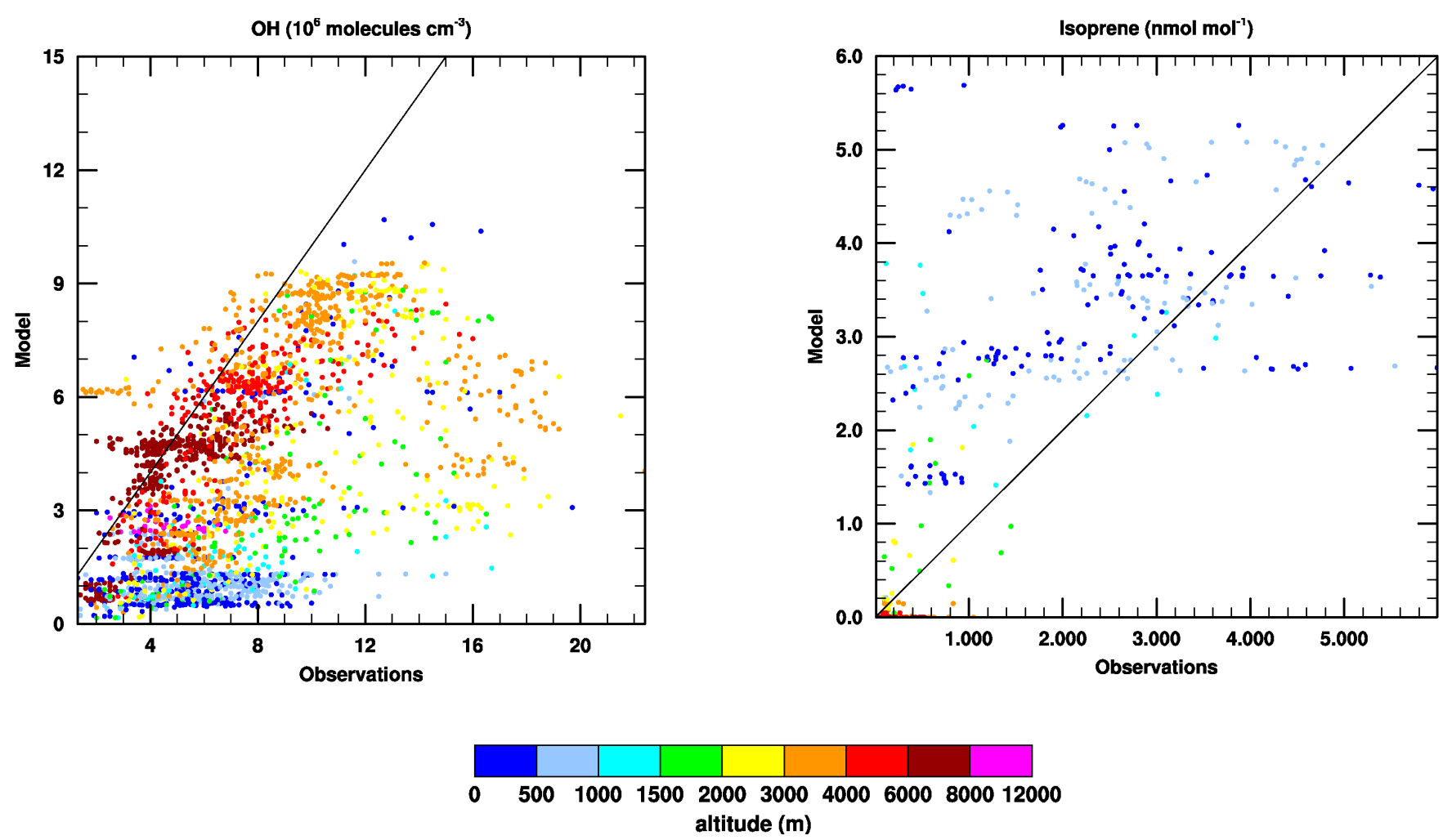

Fig. 4. Model-measurement comparison for $\mathrm{OH}$ and isoprene observed during GABRIEL for the MIMvK model run.

likely due, at least in part, to the fact that in MIM, the species MVK is a lumped species which includes MVK, MACR, and other carbonyl compounds formed during isoprene oxidation (Pöschl et al., 2000).

Mixing ratios of $\mathrm{CH}_{3} \mathrm{CHO}$ and $\mathrm{HCHO}$, both intermediate products in isoprene oxidation which also have non-isoprene related chemical sources as well as surface sources, are respectively underestimated $\left(\mathrm{CH}_{3} \mathrm{CHO}\right)$ and overestimated (HCHO) in the MIMvK simulation, when compared with the GABRIEL measurements. The disagreement between model and measurements is especially interesting for the total mixing ratio of all organic peroxides. Whereas our model simulates high mixing ratios of organic peroxides at low altitudes (which are mostly peroxides formed during isoprene oxidation), and low mixing ratios of organic peroxides at higher altitudes (which are mostly $\mathrm{CH}_{3} \mathrm{OOH}$ formed during oxidation of $\mathrm{CH}_{4}$ ), the organic peroxide measurements taken during the GABRIEL campaign show a much smaller vertical gradient, with lower mixing ratios in the mixed layer and higher mixing ratios in the free troposphere than we simulate in our model. The precise nature of these organic peroxides measured at high altitudes during the GABRIEL campaign is unknown.

The MIMvK mechanism has a number of problems in its treatment of isoprene oxidation. Taraborrelli et al. (2008) describe a new isoprene oxidation mechanism, MIM2 (Mainz
Isoprene Mechanism, version 2). This mechanism has been shown to agree closely with the much more detailed MCM (Master Chemical Mechanism, Saunders et al., 2003). Improvements in the representation of isoprene oxidation chemistry include more explicit representation of intermediate oxidation products, such as the peroxy radicals (and associated peroxides) formed from reaction of isoprene with $\mathrm{OH}$, explicit representation of MVK and MACR, which had been lumped together along with other carbonyl species in the previous MIM (as used in MIMvK), and the inclusion of previously neglected production pathways of $\mathrm{CH}_{3} \mathrm{CHO}$.

In Fig. 5 we show the effect of using this new isoprene oxidation mechanism on the comparison between our model and the GABRIEL measurements of $\mathrm{OH}$ and isoprene. Despite the many revisions to the chemical mechanism and concomitant improvements in the comparison of modelled species with observations, on the whole our simulation of the atmospheric chemistry over the Guyanas still compares poorly with the measurements. The agreement between modelled and measured $\mathrm{OH}$ and is only slightly improved, although the approximately $50 \%$ increase in mixed layer $\mathrm{OH}$ compared with the MIMvK run does lead to a decrease in the modelled isoprene, which now appears, at least on average, to be well simulated by our model. We do not simulate the high variability present in the isoprene observations. 

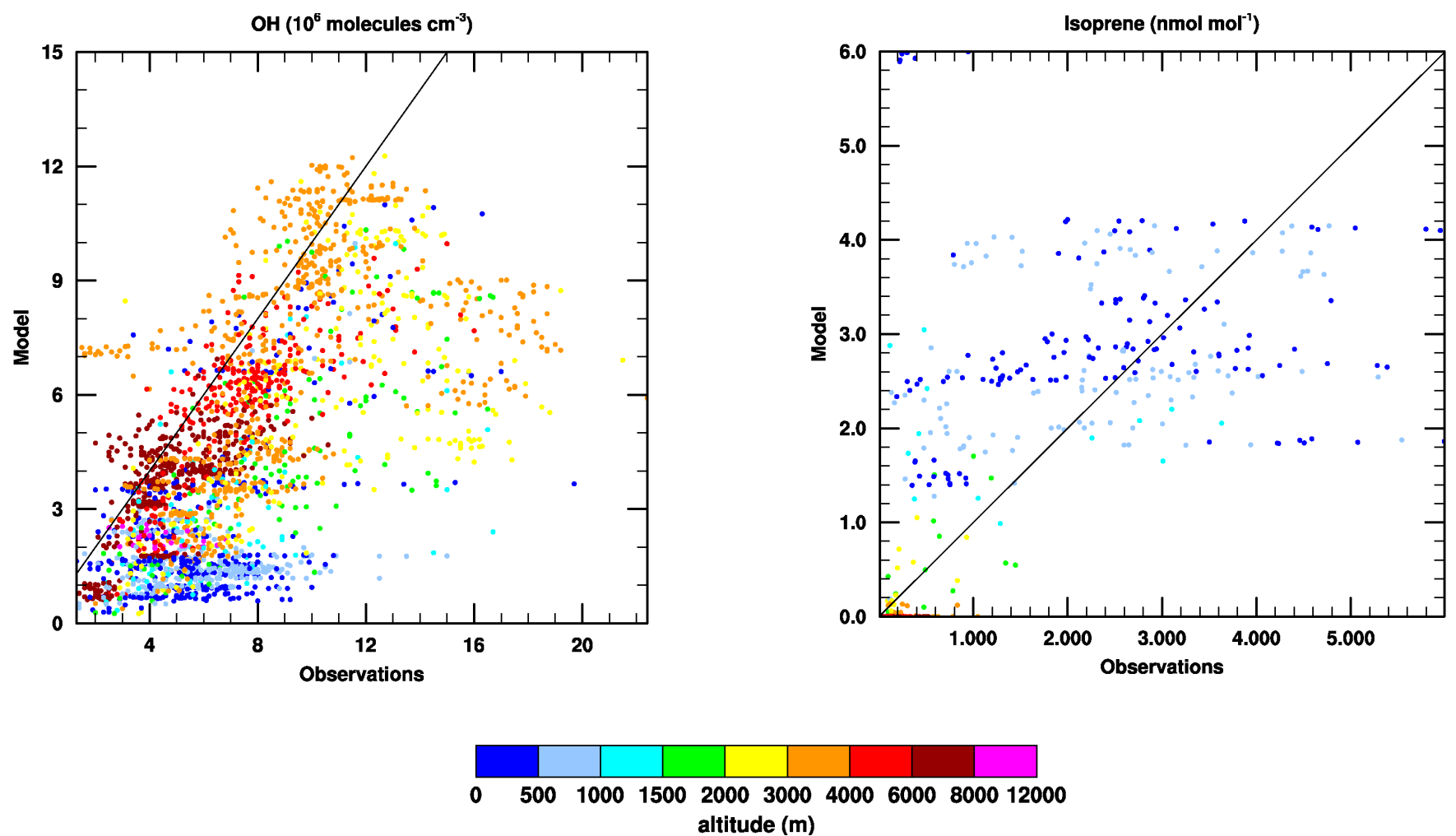

Fig. 5. Model-measurement comparison for $\mathrm{OH}$ and isoprene observed during GABRIEL for the MIM2 model run.

Comparisons of our MIM2 model run with other species measured during the GABRIEL campaign are shown in Fig. 3 of the Electronic Supplement http://www.atmos-chem-phys.net/8/4529/2008/ acp-8-4529-2008-supplement.pdf to this paper. There is considerable improvement in the model/measurement comparison of the sum of MACR and MVK (which are treated as separate species in MIM2). Modelled mixing ratios of both $\mathrm{CH}_{3} \mathrm{CHO}$ and $\mathrm{HCHO}$ increase using MIM2, which improves the model-measurement agreement for $\mathrm{CH}_{3} \mathrm{CHO}$ and worsens the agreement for $\mathrm{HCHO}$. The MIM2 mechanism does not reproduce the high mixing ratios of organic peroxides observed in the free troposphere over the Guyanas, but their mixing ratios in the mixed layer over the Guyanas are reduced compared with the MIMvK run, improving the agreement with the GABRIEL mixed layer measurements.

Kubistin et al. (2008), using a box model, find that they are best able to simulate the GABRIEL OH measurements by simple omission of the isoprene oxidation chemistry. From a chemical budget analysis of our model (using both the MIMvK mechanism and the MIM2 mechanism), we find that globally, each molecule of isoprene emitted to the atmosphere ultimately forms about three molecules of carbon monoxide. In order to examine the effect of omitting isoprene from our global model, we switch off the isoprene flux, and replace it with a mass of $60 \%$ equivalent carbon as CO. Global average $\mathrm{CO}$ mixing ratios are not changed significantly by this, although there are differences in the vicinity of isoprene source regions. Similarly, the $\mathrm{OH}$ concentration is increased over previously isoprene-emitting regions and decreased elsewhere.

We show the effect of this change on the comparison with the GABRIEL $\mathrm{OH}$ measurements in Fig. 6. Without the large sink of $\mathrm{OH}$ due to reaction with isoprene, the model now significantly overestimates the $\mathrm{OH}$ concentration in the lower part of the mixed layer, as we might expect given our overestimation of $\mathrm{OH}$ primary production in this region (Fig. 2). Model-measurement comparisons for other species measured during the campaign are shown in Fig. 4 of the Electronic Supplement http://www.atmos-chem-phys.net/8/ 4529/2008/acp-8-4529-2008-supplement.pdf to this paper. $\mathrm{HO}_{2}$ is still underestimated in the model, and the modelled $\mathrm{HO}_{2} / \mathrm{OH}$ ratio, which is greater than the measured ratio in the two runs involving isoprene, becomes lower than the measured ratio in the run with isoprene replaced by $\mathrm{CO}$. These changes to $\mathrm{OH}$ and $\mathrm{HO}_{2}$ are most pronounced in the mixed layer. The mixing ratio of all organic peroxides at low altitudes is reduced considerably in this simulation due to the lack of higher-order peroxides produced during isoprene oxidation. Our representation of $\mathrm{HCHO}$ has improved in this simulation, suggesting that our isoprene oxidation mecha- 
nisms are producing too much $\mathrm{HCHO} . \mathrm{CH}_{3} \mathrm{CHO}$ mixing ratios in this simulation, on the other hand, do not change so much compared with the isoprene-containing simulations.

Ozonolysis of highly reactive as-yet unidentified NMHC has been suggested as a possible source of $\mathrm{OH}$ in the atmosphere (Kurpius and Goldstein, 2003; Di Carlo et al., 2004), although these compounds are also likely to be removed efficiently within the forest canopy (Ciccioli et al., 1999), and their impact on the atmosphere is likely to be restricted to the formation of aerosol particles (Goldstein and Galbally, 2007). As these as-yet unidentified NMHC are also likely to be highly reactive toward $\mathrm{OH}$ radicals, it is unclear whether they would represent a net source or a net sink of $\mathrm{OH}$ radicals. While we cannot rule out the possibility of an as-yet unidentified source of $\mathrm{OH}$ from unknown, highly reactive NMHC, we do note that the $\mathrm{OH}$ chemistry of the Guyanas, as simulated by our model, is highly sensitive to the treatment of isoprene.

\subsection{Artificially enhanced $\mathrm{OH}$ recycling}

Following the hypothesis of Lelieveld et al. (2008), that isoprene oxidation in nature recycles more $\mathrm{OH}$ radicals than the isoprene oxidation mechanisms currently in our model, we look within the isoprene oxidation mechanism itself for the missing $\mathrm{OH}$. From a chemical budget analysis of our model, in which we calculate every possible isoprene degradation pathway from our chemical mechanisms based on globally averaged reaction rates, keeping track of side-effects and end products along the way, we find that globally, for October, the MIMvK mechanism recycles approximately $5 \%$ of all $\mathrm{OH}$ radicals consumed during the isoprene oxidation chain. MIM2 recycles about $10 \%$. We define this $\mathrm{OH}$ recycling as the total number of $\mathrm{OH}$ radicals produced during all steps of the oxidation of isoprene to longer lived end products (mostly $\mathrm{CO}$ ), divided by the total number of $\mathrm{OH}$ radicals consumed during this process, expressed as a percentage.

In order to estimate the amount of additional $\mathrm{OH}$ production required to match the GABRIEL measurements, we introduce an artificial source of $\mathrm{OH}$ into our isoprene oxidation mechanism. The first generation products of isoprene oxidation due to the $\mathrm{OH}$ radical are peroxy radicals. In regions of high $\mathrm{NO}_{\mathrm{x}}$ these isoprene peroxy radicals react predominantly with $\mathrm{NO}$ to form carbonyl compounds. In regions of low $\mathrm{NO}_{\mathrm{x}}$, these isoprene peroxy radicals react more frequently with $\mathrm{HO}_{2}$ to form isoprene peroxides, as shown in Eq. (1), where $\mathrm{ISO}_{2}$ and $\mathrm{ISOOH}$ respectively represent all isoprene peroxy radicals and isoprene peroxides.

$\mathrm{ISO}_{2}+\mathrm{HO}_{2} \rightarrow \mathrm{ISOOH}$

In order to simulate an additional production of $\mathrm{OH}$ radicals in low $\mathrm{NO}_{\mathrm{x}}$ regions, we add an artificial production of $\mathrm{OH}$ to these reactions between first generation peroxy radicals of isoprene and $\mathrm{HO}_{2}$ radicals, as shown in Eq. (2).

$\mathrm{ISO}_{2}+\mathrm{HO}_{2} \rightarrow n \mathrm{OH}+\mathrm{ISOOH}$

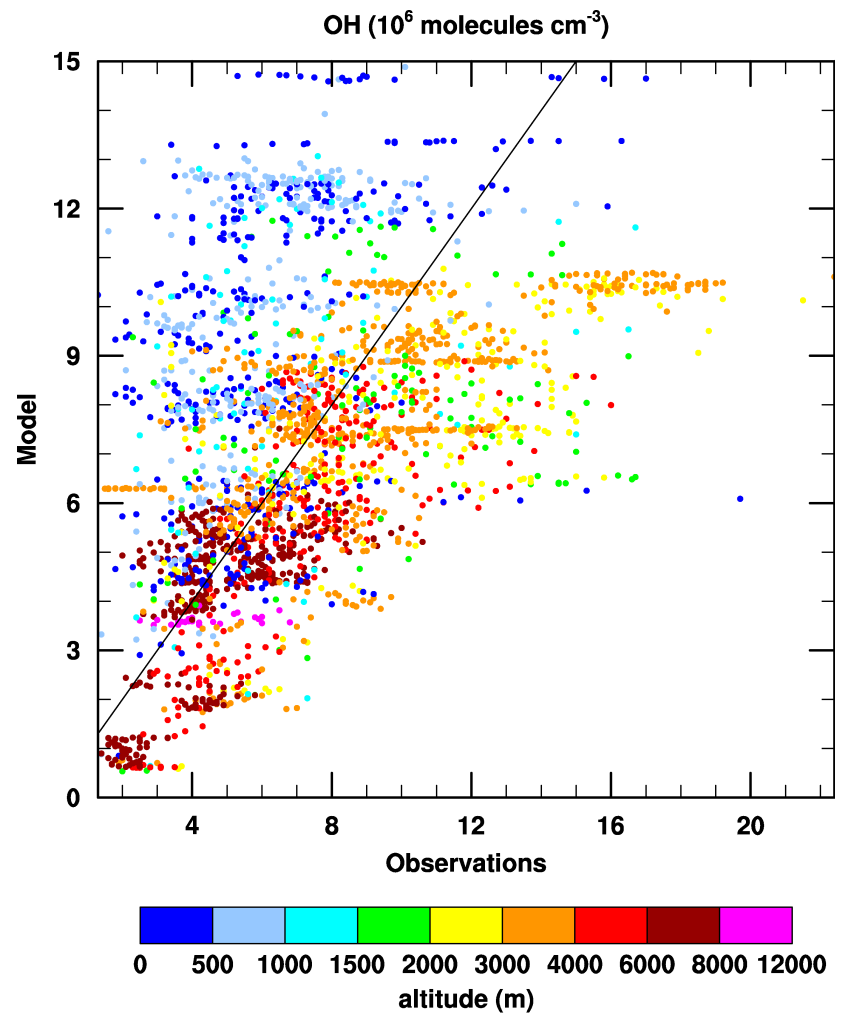

Fig. 6. Model-measurement comparison for $\mathrm{OH}$ observed during GABRIEL for the model run performed without isoprene.

We can vary the amount of this artificial $\mathrm{OH}$ production by varying the stoichiometric coefficient $n$ of $\mathrm{OH}$ in the list of products for each of these reactions.

Figure 5 of the Electronic Supplement http://www.atmos-chem-phys.net/8/4529/2008/

acp-8-4529-2008-supplement.pdf to this paper shows the effect of adding progressively more artificial $\mathrm{OH}$ production to the MIM2 mechanism. From left to right we show the cases with one, two, and three $\mathrm{OH}$ radicals produced from these reactions. From top to bottom we show the vertical profile of the modelled $\mathrm{OH}$ chemical budget over the Suriname grid cell (including the production of artificial $\mathrm{OH}$ ), the model-measurement comparison for $\mathrm{OH}$, and the model-measurement comparison for isoprene.

There is a trade-off in our model between reproducing the isoprene measurements well and reproducing the $\mathrm{OH}$ measurements well. We achieve good agreement between the observed and modelled $\mathrm{OH}$ concentrations when we add three artificial $\mathrm{OH}$ radicals as products to the reactions of first generation peroxides of isoprene with $\mathrm{HO}_{2}$ (Eq. 2). In this case, however, the modelled isoprene ratios fall below $1 \mathrm{nmol} \mathrm{mol}^{-1}$, which is well below the mean isoprene mixing ratio measured during GABRIEL. The case with two artificial $\mathrm{OH}$ radicals increases the simulated $\mathrm{OH}$ in the mixed layer over the Guyanas by approximately a factor 

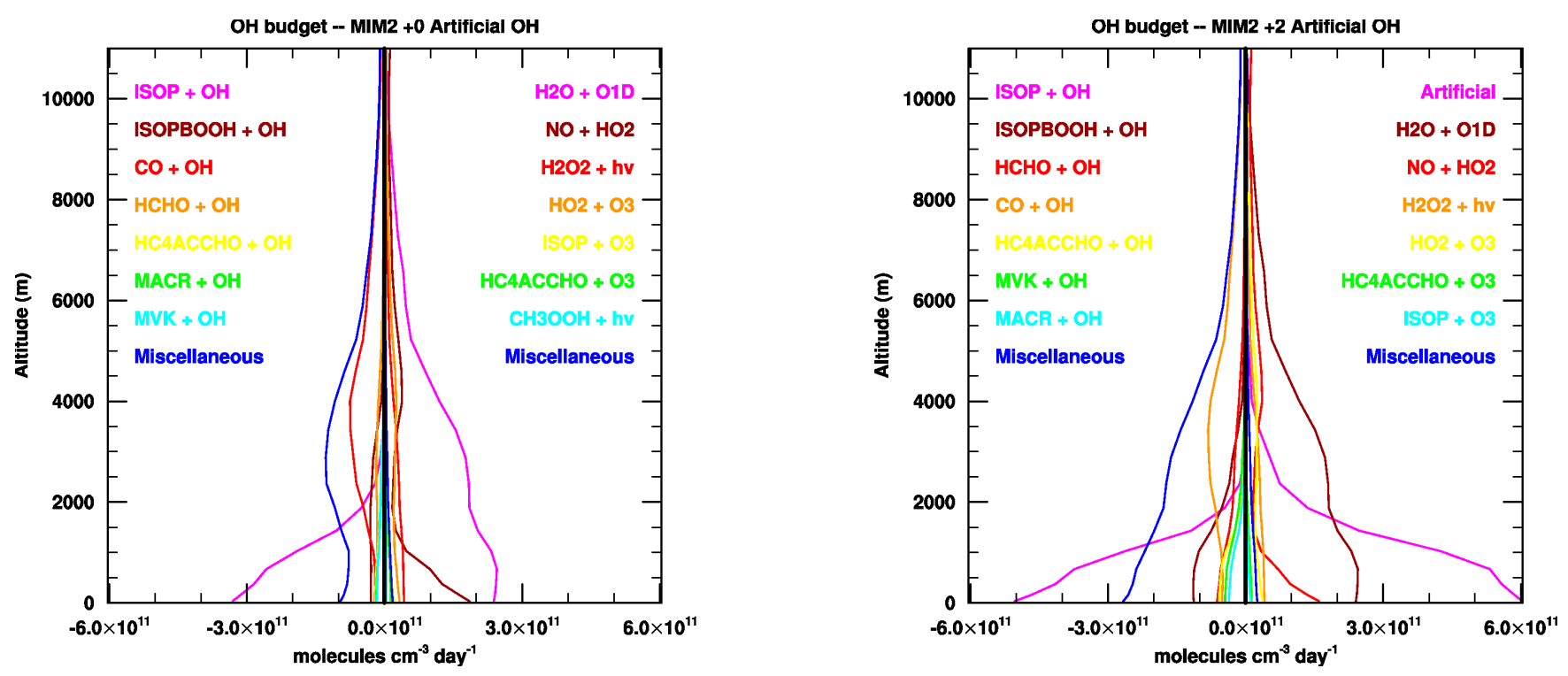

Fig. 7. Diurnally integrated vertical profiles of the modelled OH budget over the Suriname grid cell for the model runs without (left) and with (right) artificially enhanced $\mathrm{OH}$ recycling

of two, bringing these modelled $\mathrm{OH}$ concentrations closer to the lower bound of the $40 \%$ uncertainty in the measurements. This case seems to represent a good compromise between well-simulated $\mathrm{OH}$ and well-simulated isoprene, modelled mixing ratios of which are reduced by almost a factor of two compared with the MIM2 case. This corresponds with a global mean October $\mathrm{OH}$ recycling efficiency of $40 \%$ (increased from $10 \%$ in MIM2), and also corresponds to an additional source of two artificial $\mathrm{OH}$ radicals for every molecule of isoprene oxidised globally. This can also be expressed as a net cost of $\mathrm{OH}$ radicals for the entire global isoprene oxidation chain. The unaltered MIM2 mechanism requires four $\mathrm{OH}$ radicals for the oxidation of isoprene to its end products. The addition of two artificial $\mathrm{OH}$ radicals in Eq. (2) reduces this net cost of isoprene oxidation to three $\mathrm{OH}$ radicals per isoprene molecule, not to two radicals, as might be expected, because the extra $\mathrm{OH}$ leads to less photolysis of isoprene oxidation intermediates, which become more likely to react with $\mathrm{OH}$.

We show the vertical profiles of the diurnally integrated $\mathrm{OH}$ budget terms in the Suriname grid cell from model runs performed with both $n=0$ and $n=2$ (Eq. 2) in Fig. 7. The new "artificial" source of $\mathrm{OH}$ becomes the dominant production term in the $\mathrm{OH}$ budget below about $2000 \mathrm{~m}$ altitude, and is comparable in magnitude to the $\mathrm{OH}$ sink due to reaction with isoprene in this grid cell. We show the comparison of $\mathrm{OH}$ and isoprene from this run with the GABRIEL measurements in Fig. 8. Comparisons with other species measured during the campaign are shown in Fig. 6 of the Electronic Supplement http://www.atmos-chem-phys.net/8/4529/2008/ acp-8-4529-2008-supplement.pdf to this paper. The effect on $\mathrm{HO}_{2}$ of adding this artificial source of $\mathrm{OH}$ is small com- pared with the change in $\mathrm{OH}$, but these combined changes are enough to bring the modelled $\mathrm{HO}_{2} / \mathrm{OH}$ into good agreement. The modelled mixing ratios of the isoprene oxidation intermediates do not change as much as either the modelled $\mathrm{OH}$ concentration or the modelled isoprene mixing ratio. Furthermore, they do not all change in the same direction with the addition of artificial $\mathrm{OH}$. Compared with the base MIM2 run (Fig. 5 in this paper, and Fig. 3 of the Electronic Supplement http://www.atmos-chem-phys.net/8/4529/2008/ acp-8-4529-2008-supplement.pdf to this paper), the MIM2 run with artificial $\mathrm{OH}$ recycling produces increased mixing ratios of organic peroxides and $\mathrm{HCHO}$, but decreased mixing ratios of $\mathrm{CH}_{3} \mathrm{CHO}$ and MVK+MACR. This has a mixed effect on the comparison of our model with the GABRIEL observations: MACR+MVK improves, while the modelmeasurement comparison of organic peroxides, $\mathrm{HCHO}$ and $\mathrm{CH}_{3} \mathrm{CHO}$ gets worse.

\subsection{Isoprene chemistry and mixing}

The problem remains that even with this relatively modest amount of extra $\mathrm{OH}$ (our simulated $\mathrm{OH}$ in the mixed layer is still about half of the $\mathrm{OH}$ concentration measured over the Guyanas), the model now severely underestimates the isoprene mixing ratio observed over Suriname. Given that we appear to be simulating the vertical mixing of isoprene within the mixed layer well (Fig. 3), possible reasons for this underestimation of the isoprene mixing ratio are that we are underestimating the flux of isoprene to the atmosphere in our model, or that we overestimate the effective rate constant for the reaction of $\mathrm{OH}$ with isoprene. 

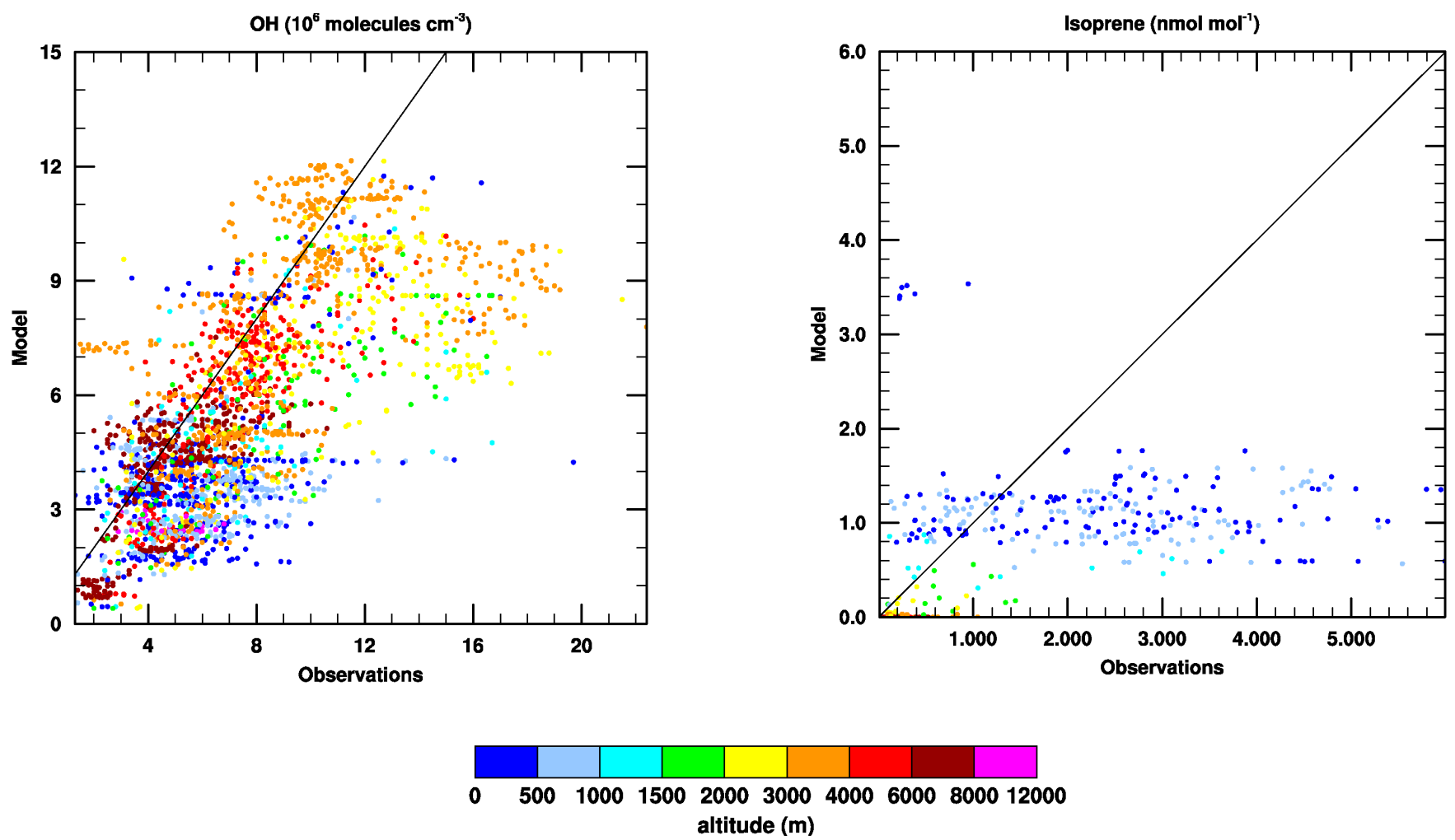

Fig. 8. Model-measurement comparison for $\mathrm{OH}$ and isoprene observed during GABRIEL for the run performed with MIM2 and two artificial $\mathrm{OH}$ radicals produced from the reaction of $\mathrm{HO}_{2}$ with peroxides of isoprene.

Guenther et al. (2006) state an upper estimate on the global isoprene source of $660 \mathrm{Tg}(\mathrm{C}) / \mathrm{yr}$. This is $32 \%$ higher than the global annual isoprene flux in our model. Although our modelled isoprene flux is comparable to the isoprene flux derived from GABRIEL measurements (Sect. 3), we explore the effect of an increased isoprene flux in our model by performing a run with the global isoprene flux increased by $50 \%$. We show the results of this run in Fig. 9. Compared with the run with the normal isoprene flux and two artificial $\mathrm{OH}$ radicals (Fig. 8), we improve the agreement between our modelled isoprene mixing ratios and those measured during GABRIEL when we increase the global isoprene flux in our model. Our modelled $\mathrm{OH}$ concentrations, however, which were already at the lower bound of the measurement uncertainty, are reduced to below the lower uncertainty bound for the measurements.

We show the model-measurement comparison for other species measured during the campaign in Fig. 7 of the Electronic Supplement http://www.atmos-chem-phys.net/8/ 4529/2008/acp-8-4529-2008-supplement.pdf to this paper. Our modelled mixing ratios of $\mathrm{CO}$, which can be considered an end product of isoprene oxidation, are increased in our run with the higher isoprene flux, both in the mixed layer and in the free troposphere, degrading the model-measurement agreement. As the free troposphere over the Guyanas is strongly influenced by global background conditions, this increase in free tropospheric $\mathrm{CO}$ over the Guyanas represents the increase in global background $\mathrm{CO}$ due to a $50 \%$ larger global isoprene flux. The poorer agreement with the GABRIEL measurements when we increase the global isoprene flux indicates that our original global isoprene flux is more consistent with global background $\mathrm{CO}$.

All of our modelled isoprene oxidation intermediates are also increased in this run, degrading the agreement with the measurements for organic peroxides, MACR+MVK and HCHO. It is possible that isoprene oxidation in nature recycles even more $\mathrm{OH}$ than the two $\mathrm{OH}$ radicals we assume in these runs. If we were to add yet more artificial $\mathrm{OH}$ recycling to our mechanism, then we would remove more MACR and MVK, improving our agreement with the measurements, but this extra $\mathrm{OH}$ would also remove isoprene, which would degrade our agreement with the measurements. This would then require us to increase the isoprene flux again. Perhaps there is some point at which an increased isoprene flux combined with increased $\mathrm{OH}$ recycling could produce agreement with measurements of both $\mathrm{OH}$ and isoprene, but we argue that this would also lead to more production of both $\mathrm{CO}$ and $\mathrm{HCHO}$, which are already overestimated in this run based on the estimated upper limit of the global annual isoprene flux. We also note that it is currently impossible to explain the true 

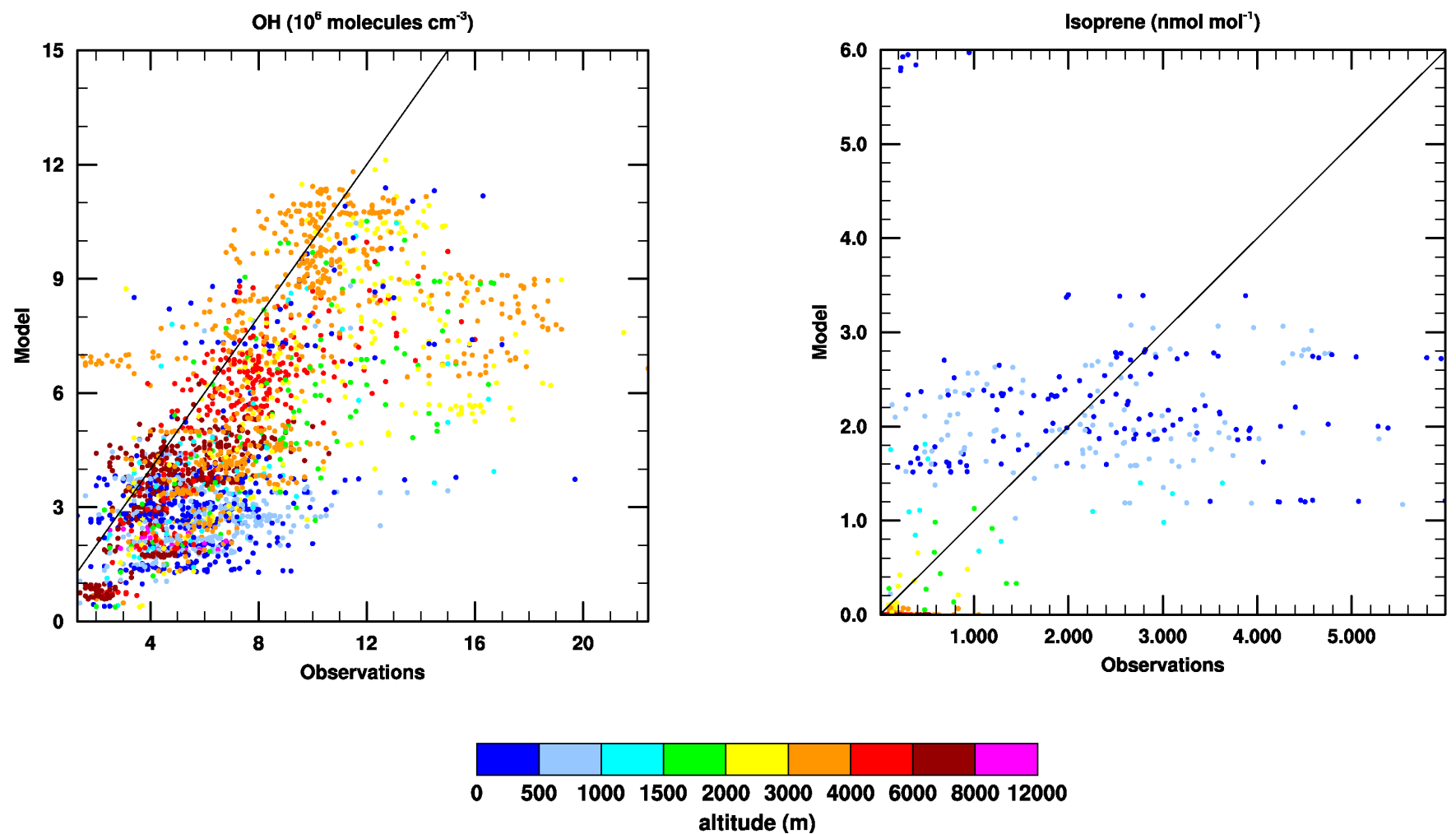

Fig. 9. Model-measurement comparison for $\mathrm{OH}$ and isoprene observed during GABRIEL for the run with both artificial $\mathrm{OH}$ and a $50 \%$ increase in the global isoprene flux.

origin of our artificial $\mathrm{OH}$. If we were to add more of this artificial $\mathrm{OH}$, explaining its origin would become even more difficult. From this we conclude that our original isoprene flux, both globally and from the Guyanas, is more consistent with the GABRIEL measurements than any increased flux.

The current IUPAC recommendation quotes a lower limit for the rate constant of isoprene+OH which is about $20 \%$ lower than the rate constant we use in our model. This lower value for the rate has also recently been confirmed by Campuzano-Jost et al. (2004). We have done a model run with this rate reduced by $20 \%$, and noticed a $20 \%$ increase in isoprene mixing ratios, with negligible effect on $\mathrm{OH}$.

Krol et al. (2000) show that effective rate constants for reactions of hydrocarbons with $\mathrm{OH}$ can be reduced by up to $30 \%$ compared with box model simulations of the mixed layer (where perfect mixing is implicitly assumed) when a heterogeneously distributed surface flux combined with inefficient mixing in the mixed layer leads to segregation of these reactive hydrocarbons from $\mathrm{OH}$. This effect is largest when the chemical lifetime of the reactive hydrocarbon $\left(\tau_{\text {chem }}\right)$ is comparable to the turbulent mixing timescale $\left(\tau_{\text {mix }}\right)$, or $D a \approx 1$, where $D a$ is the Damköhler number, defined as

$D a=\frac{\tau_{\text {mix }}}{\tau_{\text {chem }}}$
For the case shown in Fig. 8, our model calculates an isoprene lifetime of about half an hour in the mixed layer over the Guyanas. Recall that the $\mathrm{OH}$ concentration measured in the mixed layer during GABRIEL is approximately double what we simulate in this model run, implying an even shorter bulk lifetime for isoprene. Eerdekens et al. (2008) calculate a convective mixing timescale of about between 8 and 16 min during the GABRIEL campaign, which is similar to the $10 \mathrm{~min}$ "eddy turnover timescale" used in the Large Eddy Simulation (LES) modelling literature (Agee and Gluhovsky, 1999; Anfossi et al., 2006). It seems that we have a Damköhler number for isoprene of the order of unity over the Guyanas.

Verver et al. (2000) studied the isoprene+OH system and noticed no significant segregation effects, however their modelled $\mathrm{OH}$ concentrations were quite low $\left(\approx 5 \times 10^{5}\right.$ molecules $/ \mathrm{cm}^{3}$, or an order of magnitude lower than those measured during the GABRIEL campaign), leading to substantially lower values of the Damköhler number for isoprene than we calculate for our model. Our model generally contains about eight resolved levels in the mixed layer over Suriname during the afternoon when the height of the mixed layer is at its greatest, but is not capable of resolving the turbulent eddys which are responsible for mixing in the mixed layer. This is clearly an issue which deserves future attention with more resolved models. 

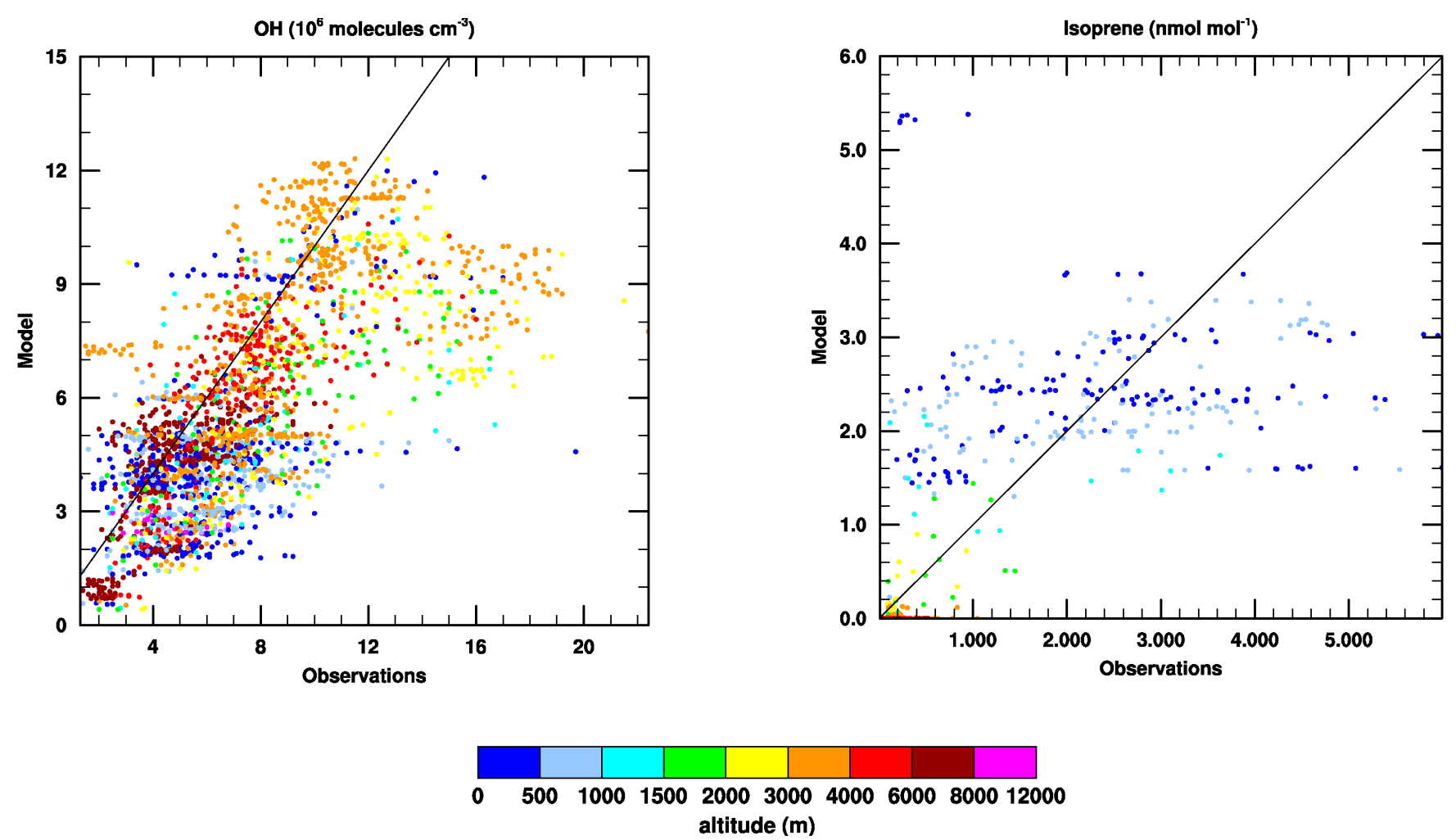

Fig. 10. Model-measurement comparison for $\mathrm{OH}$ and isoprene observed during GABRIEL for the run with both artificial OH and the reduced rate constant for isoprene+OH.

We have calculated the intensity of segregation between isoprene and $\mathrm{OH}$ from the GABRIEL measurements of $\mathrm{OH}$ and isoprene using the formula

$$
<I_{S, A+B}>=\frac{<A^{\prime} B^{\prime}>}{<A><B>}
$$

where $A$ and $B$ are the concentrations of isoprene and $\mathrm{OH}$, primes represent deviations from the average, and angle brackets represent averages over all of the GABRIEL measurements for which valid measurements of $\mathrm{OH}$ and isoprene coincide. The intensity of segregation influences the volumeaveraged effective reaction rate constant $<k_{A+B}>$ according to the formula

$$
<k_{A+B}>=k_{A+B}\left(1+<I_{S, A+B}>\right)
$$

where $k_{A+B}$ is the laboratory rate constant. Positively correlated deviations of $A$ and $B$ lead to a higher effective rate constant, while anticorrelated deviations reduce the effective rate constant. Based on $5 \mathrm{~s}$ average $\mathrm{OH}$ measurements, and approximately $2 \mathrm{~s}$ average isoprene measurements falling inside these $5 \mathrm{~s} \mathrm{OH}$ measurement windows, we calculate an intensity of segregation between $\mathrm{OH}$ and isoprene of -0.13 , which corresponds to a reduction in the effective rate constant of $13 \%$. Due to this $5 \mathrm{~s}$ averaging time combined with the high speed of the aircraft in the mixed layer $\left(>100 \mathrm{~ms}^{-1}\right)$, these measurements can not be expected to capture the fine structures involved in mixing. These measurements represent averaged conditions over larger spatial scales than the scales over which we expect reactants to be segregated. We expect, therefore, that the intensity of segregation between isoprene and $\mathrm{OH}$ in the mixed layer over the Guyanas in October 2005 will have been more negative than the -0.13 which we calculate from the GABRIEL measurements.

Based on our previously noted insensitivity of $\mathrm{OH}$ concentration to changes to the effective $\mathrm{OH}+\mathrm{isoprene}$ rate constant, as well as our underestimation of isoprene mixing ratio by approximately $50 \%$ in our run with a production of two artificial $\mathrm{OH}$ radicals (Fig. 8), we determine that a reduction in the effective $\mathrm{OH}+\mathrm{isoprene}$ rate constant of $50 \%$ (relative to the lower bound of the range recommended by IUPAC) is necessary to produce good agreement between model and measurements. We show the model-measurement comparison of $\mathrm{OH}$ and isoprene for this simulation (still with a production of two artificial $\mathrm{OH}$ radicals in Eq. 2) in Fig. 10. This is equivalent to an intensity of segregation between isoprene and $\mathrm{OH}$ of -0.5 . We note that this method of determining the intensity of segregation should be considered a "top-down" approach, in which we effectively treat $\left\langle I_{S, A+B}\right\rangle$ as the single unknown in Eq. (4). The effect of this reduction in the isoprene $+\mathrm{OH}$ rate constant is an approximate doubling of the simulated isoprene mixing ratio 
over the Guyanas when compared with the run using MIM2 with two artificial $\mathrm{OH}$ radicals. The simulated isoprene is now in much better agreement with the GABRIEL measurements. The effect on $\mathrm{OH}$ of this change is fairly small, although simulated $\mathrm{OH}$ from this run is slightly closer to the GABRIEL measurements than in the previous run. We show the model-measurement comparison for other species measured during the campaign in Fig. 8 of the Electronic Supplement http://www.atmos-chem-phys.net/8/4529/2008/ acp-8-4529-2008-supplement.pdf to this paper. The change in the isoprene+ $\mathrm{OH}$ rate constant reduces the modelled mixing ratios of organic peroxides and MACR+MVK (bringing these modelled mixing ratios closer to the mixing ratios observed during the GABRIEL campaign). Simulated mixing ratios of $\mathrm{CH}_{3} \mathrm{CHO}$ and $\mathrm{HCHO}$ remain largely unchanged in this simulation compared with the previous simulation. We still underestimate the $\mathrm{CH}_{3} \mathrm{CHO}$ measurements and overestimate the $\mathrm{HCHO}$ measurements.

Krol et al. (2000) found that the intensity of segregation between reactive hydrocarbons and $\mathrm{OH}$ is increased when the heterogeneity of the surface flux is taken into account, and they report a maximum effect on the average bulk reaction rates between reactive hydrocarbons and $\mathrm{OH}$ of $30 \%$. This corresponds with an intensity of segregation of -0.3 , which is not as great as the -0.5 which we must assume if our model is to agree with both the $\mathrm{OH}$ and the isoprene measured during GABRIEL. In order to avoid numerical instabilities in their model, Krol et al. (2000) used a surface flux of reactive hydrocarbon which was distributed according to a relatively smooth Gaussian emission function. The isoprene flux at the forest canopy can be expected to be more heterogeneously distributed still, and therefore lead to a larger intensity of segregation between isoprene and $\mathrm{OH}$, and therefore a larger reduction in the effective rate constant for reaction between $\mathrm{OH}$ and isoprene than the $30 \%$ suggested by Krol et al. (2000) as a maximum effect. It is also reasonable to expect that the isoprene flux at the forest canopy coincides with fluxes of other, more reactive NMHC, and that these NMHC may deplete $\mathrm{OH}$ in isoprene-rich dry convective plumes, which may amplify the intensity of segregation between isoprene and $\mathrm{OH}$, thus further lowering the effective rate constant for reaction between $\mathrm{OH}$ and isoprene.

LES studies (Avissar and Schmidt, 1998) have found that the influence of heterogeneity in the surface heat flux on boundary layer dynamics largely decreases if the winds are stronger than approximately $2.5 \mathrm{~ms}^{-1}$. We have examined the routine observations taken at the observing station "SJMP", which is located at Zanderij International Airport, the base used by the learjet during the GABRIEL campaign. Filtering these data for observations taken during the campaign between the hours of 12:00 UTC and 20:00 UTC (the times of day during which GABRIEL flights were made), we find (based on 59 observations) that the average wind speed was $3 \mathrm{~ms}^{-1}$, with a standard deviation of $1.5 \mathrm{~ms}^{-1}$. Calm conditions were reported $8.5 \%$ of the time. The influence of wind speed on the effect of heterogeneities in the surface flux of reactive trace gasses remains an interesting topic for future investigation.

\section{Global implications}

In order to examine the global implications of our changes to the isoprene oxidation mechanism, the $\mathrm{OH}$ recycling efficiency, and the effective rate constants in the isoprene-OH system, we have performed four year-long simulations: a simulation with the MIMvK mechanism (MIMvK); a simulation with the MIM2 mechanism (MIM2); a simulation with MIM2 and a production of 2.5 artificial $\mathrm{OH}$ radicals from Eq. (2) (MIM2+); and a simulation with MIM2 including a production of 2.0 artificial $\mathrm{OH}$ radicals from Eq. (2), and with an effective rate constant for reaction between $\mathrm{OH}$ and isoprene of 50\% lower than the lower bound recommended by IUPAC (MIM2+Slow). Of course, the 50\% intensity of segregation which we have determined here is necessary in order to correctly simulate both isoprene and $\mathrm{OH}$ is only applicable to the Guyanas, but we examine the effects of applying it to the whole globe in our last sensitivity simulation.

For our MIMvK simulation, we calculate a global methane lifetime of $7.3 \mathrm{yr}$. Our calculated methane lifetime is $0.1 \mathrm{yr}$ shorter than the lower uncertainty bound of the methane lifetime quoted in the IPCC-AR4 $(8.7 \pm 1.3 \mathrm{yr}$, Denman et al., 2007). Compared with a 26 -model intercomparison (Stevenson et al., 2006), our methane lifetime is 1.1 standard deviations below the model ensemble mean methane lifetime of 8.7 yr. For our MIM2+Slow run, we calculate a methane lifetime of $7.0 \mathrm{yr}$. The effect of all of our changes to the isoprene oxidation mechanism on the global methane lifetime is a reduction of $0.3 \mathrm{yr}$, or $4 \%$. This represents $23 \%$ of the standard deviation among the 26 models from the study of Stevenson et al. (2006).

We compare the results of each of our four year-long simulations with measurements of isoprene, $\mathrm{OH}$, and $\mathrm{NO}$ from three field campaigns (AEROBIC97, PROPHET98, and PMTACS-NY) in Table 1. It should be noted that during these campaigns $\mathrm{NO}$ mixing ratios are typically up to an order of magnitude higher than during GABRIEL, even under the selected lowest-NO conditions. We clearly do a poor job in our simulation of the AEROBIC97 campaign, significantly underestimating isoprene mixing ratios while overestimating $\mathrm{NO}$ and $\mathrm{OH}$. Harrison et al. (2001) mention that the dominant plant species in the region had not been previously thought to emit isoprene. This probably explains why our modelled isoprene emissions are so low. For PROPHET98 and PMTACS-NY, we correctly simulate low- $\mathrm{NO}_{\mathrm{x}}$ environments. Our simulated isoprene for the PROPHET98 campaign is an order of magnitude too low. Apel et al. (2002) show a peak isoprene flux over this site of about $4 \mathrm{mg}(\mathrm{C}) \mathrm{m}^{-2} \mathrm{~h}^{-1}$. Our model calculates a flux twenty times smaller than this, explaining our underestimation of the 
Table 1. Measured $\mathrm{OH}$ concentrations $\left(\times 10^{6}\right.$ molecules $\left.\mathrm{cm}^{-3}\right)$ and mixing ratios of isoprene $(\mathrm{nmol} \mathrm{mol}-1)$ and $\left.\mathrm{NO}^{-1} \mathrm{pmol} \mathrm{mol}^{-1}\right)$ at local noon from three field measurement campaigns compared with various runs of our model.

\begin{tabular}{|c|c|c|c|c|c|}
\hline \multicolumn{6}{|c|}{ AEROBIC97 } \\
\hline & Measured & MIMvK & MIM2 & MIM2+ & MIM2+ Slow \\
\hline Isoprene $^{\mathrm{a}}$ & 1 & 0.01 & 0.01 & 0.01 & 0.08 \\
\hline $\mathrm{OH}^{\mathrm{b}}$ & 4 & 16 & 15 & 16 & 15 \\
\hline $\mathrm{NO}^{\mathrm{b}}$ & $<100$ & 130 & 130 & 120 & 120 \\
\hline \multicolumn{6}{|c|}{ PROPHET98 } \\
\hline & Measured & MIMvK & MIM2 & MIM2+ & MIM2+ Slow \\
\hline Isoprene $^{c}$ & 2 & 0.3 & 0.3 & 0.1 & 0.4 \\
\hline $\mathrm{OH}^{\mathrm{d}}$ & 4 & 5 & 5 & 7 & 7 \\
\hline $\mathrm{NO}^{\mathrm{d}}$ & $<100$ & 57 & 55 & 41 & 44 \\
\hline \multicolumn{6}{|c|}{ PMTACS-NY } \\
\hline & Measured & MIMvK & MIM2 & MIM2+ & MIM2+ Slow \\
\hline Isoprene $^{\mathrm{e}}$ & $<1$ & 0.7 & 0.6 & 0.2 & 0.9 \\
\hline $\mathrm{OH}^{\mathrm{e}}$ & 3 & 5 & 5 & 8 & 8 \\
\hline $\mathrm{NO}^{\mathrm{e}}$ & $\approx 100$ & 70 & 77 & 76 & 60 \\
\hline
\end{tabular}

a Harrison et al. (2001).

b Carslaw et al. (2001).

c Apel et al. (2002).

d Tan et al. (2001).

e Ren et al. (2006).

measured isoprene mixing ratios. Without artificial $\mathrm{OH}$ recycling, our modelled OH over the PROPHET98 site is quite close to the observations. When we add this artificial recycling, our $\mathrm{OH}$ becomes a factor of two too high. Perhaps if we were to get the isoprene flux about right, we might get closer to the observed OH. For PMTACS-NY, we correctly simulate low mixing ratios of isoprene, although this is with $\mathrm{OH}$ concentrations higher than observed. If our $\mathrm{OH}$ were to be closer to the measurements, we would probably have too much isoprene. We are not aware of any measurements, either direct or indirect, of the isoprene flux during the PMTACS-NY campaign, but it appears, based on the above discussion, that our modelled flux may have been higher than the actual flux during this campaign. A possible reason for our overestimation of $\mathrm{OH}$ at this site is that our model lacks biogenic NMHC other than isoprene, which according to Ren et al. (2006) formed a very large fraction of the total $\mathrm{OH}$ reactivity measured during the PMTACS-NY campaign.

We show the effect of all of our changes to the MIM2 isoprene oxidation mechanism $(\mathrm{OH}$ recycling and reduction of the effective rate constant for $\mathrm{OH}+$ isoprene) on the chemistry of the boundary layer in Fig. 11, where we compare the MIM2+Slow model run with the MIM2 model run.
Differences between MIM2 and MIMvK are described in Taraborrelli et al. (2008). For all of the panels comparing isoprene in the mixed layer (right hand side of Fig. 11), we have restricted the comparison to grid cells which have a boundary layer integrated column density of at least $1 \times 10^{14}$ molecules $\mathrm{cm}^{-2}$, which is approximately two orders of magnitude lower than the global peak value.

From Fig. 11, we see that the Amazon region, including the Guyanas, is unique in the world, in that the combined effect of extra $\mathrm{OH}$ recycling and a reduced effective $\mathrm{OH}+\mathrm{isoprene}$ rate constant is a year-round decrease in our modelled isoprene mixing ratios in the mixed layer of between about 10 and 50\% over several contiguous model grid cells. This effect is also seen in tropical southern Africa and north eastern Australia, but is restricted to the summer and autumn months. Such large effects on our modelled isoprene mixing ratios also usually coincide with increases in our modelled $\mathrm{OH}$ radical concentrations of around $100 \%$, or a doubling of the $\mathrm{OH}$ concentration, which is necessary in order to overcome the $50 \%$ reduction in the $\mathrm{OH}+$ isoprene effective rate constant. Over other regions of the globe, and at other times of the year, the extra $\mathrm{OH}$ recycling we introduce has the effect of increasing $\mathrm{OH}$ in the mixed layer by more 

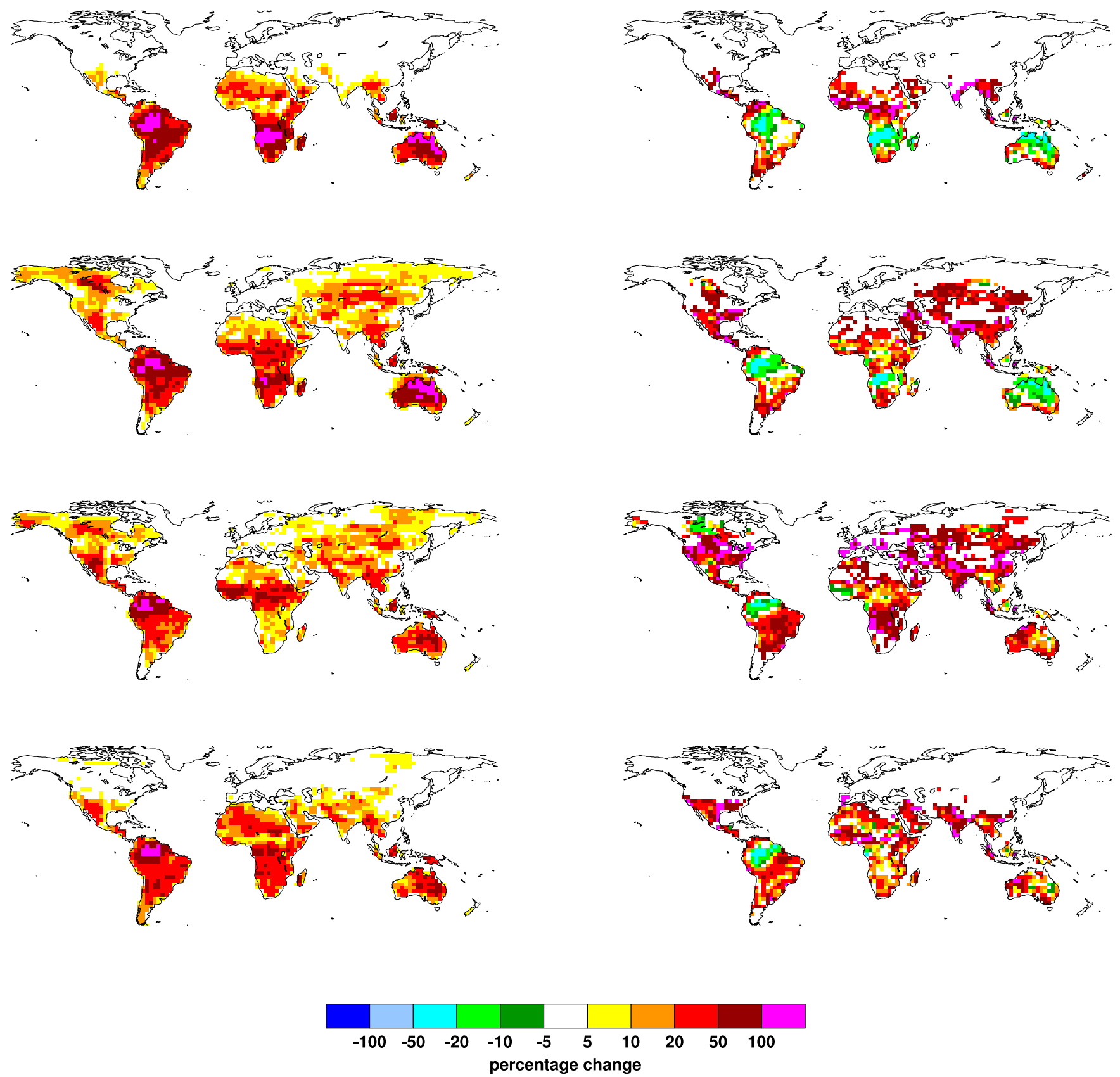

Fig. 11. Percentage change in mixed layer-integrated density of $\mathrm{OH}$ (left) and isoprene (right) in the MIM2+Slow run compared with the MIM2 run. From top to bottom we show: the seasonal averages for December, January and February; March, April, May; June, July, August; and September, October, November. 
modest amounts, leading to net increases in our modelled isoprene mixing ratios. We also notice some large increases in modelled isoprene mixing ratios in $\mathrm{NO}_{\mathrm{x}}$-rich regions (e.g. north eastern USA, India) where $\mathrm{OH}$ production due to artificial recycling is negligible, but our reduced effective rate constant is still in effect.

\section{Conclusions}

We have presented a comparison between measurements made during the GABRIEL field campaign, conducted over the Guyanas in October 2005, and model runs performed with the ECHAM5/MESSy AC-GCM. As is the case for other models, our model in its standard configuration significantly underestimates the concentration of $\mathrm{OH}$ radicals over the Amazon. This is also true for our model despite its overestimation of $\mathrm{OH}$ primary production. The addition of a fully revised isoprene oxidation mechanism does not significantly improve our simulation of $\mathrm{OH}$. In order to approach the lower uncertainty bound on the GABRIEL OH measurements, we must introduce an artificial source of $\mathrm{OH}$ into our model in regions where isoprene is oxidised by $\mathrm{OH}$ under low $\mathrm{NO}_{\mathrm{x}}$ conditions. The magnitude of our artificial $\mathrm{OH}$ source represents an increase in the $\mathrm{OH}$ recycling efficiency of the isoprene oxidation chain from $10 \%$ (under the MIM2 mechanism) to $40 \%$ (with the artificial $\mathrm{OH}$ ). This may be a conservative estimate of the required additional $\mathrm{OH}$ recycling, given the overestimation of $\mathrm{OH}$ primary production in our model. Lelieveld et al. (2008) show results from a run with an imposed recycling efficiency of $50 \%$, which produces even better agreement with the $\mathrm{OH}$ measured during GABRIEL (though a further degradation in the agreement with isoprene).

This study has not gone into detail speculating about the possible origins of the missing $\mathrm{OH}$ required by our model in order to match the GABRIEL OH measurements. We have instead focused on determining the approximate magnitude of the required extra source of $\mathrm{OH}$, and exploring some of the implications of this required $\mathrm{OH}$ source for atmospheric chemistry. Future studies will make use of new chemical mechanisms under development and compare simulations performed using these mechanisms with the GABRIEL measurements in an attempt to determine which processes might be producing the extra $\mathrm{OH}$ to which we simply refer in this study as "artificial OH". In our study, the artificial $\mathrm{OH}$ is simply added into an existing mechanism. The other product yields are therefore not consistent with there being an extra source of $\mathrm{OH}$. Organic peroxides, for example, might be reduced in future model runs involving recycling of $\mathrm{OH}$ through reactions of organic peroxy radicals or increased photolysis of the organic peroxides themselves. This may also explain why we have too much organic peroxide in the mixed layer, along with too much HCHO.
Based on our model runs, it appears highly unlikely that such high $\mathrm{OH}$ concentrations can exist in the mixed layer alongside the isoprene mixing ratios measured during GABRIEL. This apparent paradox is solved by reducing the effective rate constant for the reaction of isoprene with $\mathrm{OH}$ by about $50 \%$. The physical basis for this is the separation of the two reactants, $\mathrm{OH}$ and isoprene, within the mixed layer due to inefficient mixing. The GABRIEL measurements do not provide enough temporal and spatial resolution to confirm that this intensity of separation between isoprene and $\mathrm{OH}$ in fact existed during the GABRIEL campaign, although our argument is strengthened by the high variability in the isoprene mixing ratio observed during the campaign. We recommend further measurement in similar regions using techniques able to resolve the necessary scales.

Compared with the isoprene oxidation scheme in the MIMvK chemical mechanism, the new MIM2 mechanism produces a better agreement between the observed and modelled mixing ratios of the sum of methacrolein and methyl vinyl ketone (MACR+MVK), especially when the mechanism is adjusted to match the observed $\mathrm{OH}$ and isoprene by introducing artificial $\mathrm{OH}$ recycling and reducing the effective $\mathrm{OH}+$ isoprene rate constant. Both mechanisms, however, consistently underestimate the observed $\mathrm{CH}_{3} \mathrm{CHO}$ mixing ratios (which has implications for PAN production) and overestimate the observed HCHO (which could have implications for efforts to determine isoprene emissions using space-based observations of $\mathrm{HCHO}$ ). Measurements of total organic peroxide mixing ratios over the Guyanas are also poorly simulated by our model. Improvements to our chemical mechanism do improve the model-measurement agreement at low altitudes, but we remain unable to simulate the high mixing ratios of organic peroxides observed in the free troposphere during the GABRIEL campaign.

Our year-long model runs show that our addition of $\mathrm{OH}$ recycling and our reduction of the effective $\mathrm{OH}+$ isoprene rate constant produce a consistent year-round decrease in modelled isoprene mixing ratios over the Amazon. Overestimation of isoprene mixing ratios in this region at all times of the year has been a problem with many global atmospheric chemistry models. Our results here allow us to use isoprene fluxes in our model which are based on a large number of observations of isoprene fluxes at scales ranging from leaf to ecosystem, without overestimating the available observations of isoprene mixing ratio. We also see such a reduction in modelled isoprene mixing ratios over tropical southern Africa, and north eastern Australia during the summer and autumn months. We are not aware of any measurements of isoprene in these regions with which to compare our model output. Our combination of $\mathrm{OH}$ recycling and segregation of reactants also leads to our model predicting higher isoprene mixing ratios in some regions. In order to better understand this complex isoprene-OH oxidation system, we recommend many more field campaigns in which isoprene fluxes and mixing ratios are measured alongside $\mathrm{OH}$ and 
other supporting measurements, as well as laboratory work to better determine reaction rates and product yields of all species involved in the isoprene oxidation chain.

Acknowledgements. The authors wish to thank the GABRIEL team for their work during the field campaign in Suriname in October 2005, the ECHAM5/MESSy team for their ongoing work in developing and improving the ECHAM5/MESSy model, and T. Dillon for useful discussions.

Edited by: D. Helmig

\section{References}

Agee, E. and Gluhovsky, A.: LES model sensitivities to domains, grids, and large-eddy timescales, J. Atmos. Sci., 56, 599-604, 1999.

Anfossi, D., Rizza, U., Mangia, C., Degrazia, G. A., and Marques, E. P.: Estimation of the ratio between the Lagrangian and Eulerian time scales in an atmospheric boundary layer generated by large eddy simulation, Atmos. Environ., 40, 326-337, 2006.

Apel, E. C., Riemer, D. D., Hills, A., Baugh, W., Orlando, J., Faloona, I., Tan, D., Brune, W., Lamb, B., Westberg, H., Carroll, M. A., Thornberry, T., and Geron, C. D.: Measurement and interpretation of isoprene fluxes and isoprene, methacrolein, and methyl vinyl ketone mixing ratios at the PROPHET site during the 1998 Intensive, J. Geophys. Res., 107, 4034, doi:10.1029/2000JD000225, 2002.

Avissar, R. and Schmidt, T.: An evaluation of the scale at which ground-surface heat flux patchiness affects the convective boundary layer using large-eddy simulations, J. Atmos. Sci., 55, 26662689, 1998.

Bartenbach, S., Williams, J., Plass-Dulmer, C., Berresheim, H., and Lelieveld, J.: In-situ measurement of reactive hydrocarbons at Hohenpeissenberg with comprehensive two-dimensional gas chromatography (GC x GC-FID): use in estimating $\mathrm{HO}$ and $\mathrm{NO}_{3}$, Atmos. Chem. Phys., 7, 1-14, 2007,

http://www.atmos-chem-phys.net/7/1/2007/.

Campuzano-Jost, P., Williams, M. B., D’Ottone, L., and Hynes, A. J.: Kinetics and mechanism of the reaction of the hydroxyl radical with $\mathrm{h}(8)$-isoprene and $\mathrm{d}(8)$-isoprene: Isoprene absorption cross sections, rate coefficients, and the mechanism of hydroperoxyl radical production, J. Phys. Chem. A, 108, 15371551, 2004.

Carslaw, N., Creasy, D. J., Harrison, D., Heard, D. E., Hunter, M. C., Jacobs, P. J., Jenkin, M. E., Lee, J. D., Lewis, A. C., Pilling, M. J., Saunders, S. M., and Seakins, P. W.: $\mathrm{OH}$ and $\mathrm{HO}_{2}$ radical chemistry in a forested region of north-western Greece, Atmos. Environ., 35, 4725-4737, 2001.

Ciccioli, P., Brancaleoni, E., Frattoni, M., Palo, V. D., Valentini, R., Tirone, G., Seufert, G., Bertin, N., Hansen, U., Csiky, O., Lenz, R., and Sharma, M.: Emission of reactive terpene compounds from orange orchards and their removal by within-canopy processes, J. Geophys. Res., 104, 8077-8094, 1999.

Denman, K., Brasseur, G., Chidthaisong, A., Ciais, P., Cox, P., Dickinson, R., Hauglustaine, D., Heinze, C., Holland, E., Jacob, D., Lohmann, U., Ramachandran, S., da Silva Dias, P., Wofsy, S., and Zhang, X.: Couplings Between Changes in the Climate System and Biogeochemistry, in: Climate Change 2007: The Physi- cal Science Basis. Contribution of Working Group I to the Fourth Assessment Report of the Intergovernmental Panel on Climate Change, edited by Solomon, S., Qin, D., Manning, M., Chen, Z., Marquis, M., Averyt, K., M.Tignor, and Miller, H., Cambridge University Press, Cambridge, United Kingdom and New York, NY, USA, 2007.

Di Carlo, P., Brune, W. H., Martinez, M., Harder, H., Lesher, R., Ren, X. R., Thornberry, T., Carroll, M. A., Young, V., Shepson, P. B., Riemer, D., Apel, E., and Campbell, C.: Missing OH reactivity in a forest: Evidence for unknown reactive biogenic VOCs, Science, 304, 722-725, 2004.

Eerdekens, G., Ganzeveld, L., Vilà-Guerau de Arellano, J., Klüpfel, T., Sinha, V., Yassaa, N., Williams, J., Harder, H., Kubistin, D., Martinez, M., and Lelieveld, J.: Flux estimates of isoprene, methanol and acetone from airborne PTR-MS measurements over the tropical rainforest during the GABRIEL 2005 campaign, Atmos. Chem. Phys. Discuss, 8, 12 903-12 969, 2008.

Folberth, G. A., Hauglustaine, D. A., Lathière, J., and Brocheton, F.: Interactive chemistry in the Laboratoire de Météorologie Dynamique general circulation model: model description and impact analysis of biogenic hydrocarbons on tropospheric chemistry, Atmos. Chem. Phys., 6, 2273-2319, 2006, http://www.atmos-chem-phys.net/6/2273/2006/.

Ganzeveld, L. N., van Aardenne, J. A., Butler, T. M., Lawrence, M. G., Metzger, S. M., Stier, P., Zimmermann, P., and Lelieveld, J.: Technical Note: Anthropogenic and natural offline emissions and the online EMissions and dry DEPosition submodel EMDEP of the Modular Earth Submodel system (MESSy), Atmos. Chem. Phys. Discuss, 6, 5457-5483, 2006.

George, L. A., Hard, T. M., and O'Brien, R. J.: Measurement of free radicals $\mathrm{OH}$ and $\mathrm{HO}_{2}$ in Los Angeles smog, J. Geophys. Res., 104, 11 643-11 655, 1999.

Goldstein, A. H. and Galbally, I. E.: Known and unexplored organic constituents in the earth's atmosphere, Environ. Sci. Technol., 41, 1514-1521, 2007.

Guenther, A., Hewitt, C. N., Erickson, D., Fall, R., Geron, C., Graedel, T., Harley, P., Klinger, L., Lerdau, M., Mckay, W. A., Pierce, T., Scholes, B., Steinbrecher, R., Tallamraju, R., Taylor, J., and Zimmerman, P.: A global-model of natural volatile organic-compound emissions, J. Geophys. Res., 100, 88738892, 1995.

Guenther, A., Karl, T., Harley, P., Wiedinmyer, C., Palmer, P. I., and Geron, C.: Estimates of global terrestrial isoprene emissions using MEGAN (Model of Emissions of Gases and Aerosols from Nature), Atmos. Chem. Phys., 6, 3181-3210, 2006, http://www.atmos-chem-phys.net/6/3181/2006/.

Harrison, D., Hunter, M. C., Lewis, A. C., Seakins, P. W., Bonsang, B., Gros, V., Kanakidou, M., Touaty, M., Kavouras, I., Mihalopoulos, N., Stephanou, E., Alves, C., Nunes, T., and Pio, C.: Ambient isoprene and monoterpene concentrations in a Greek fir (Abies Borisii-regis) forest. Reconciliation with emissions measurements and effects on measured $\mathrm{OH}$ concentrations, Atmos. Environ., 35, 4699-4711, 2001.

Heard, D. E. and Pilling, M. J.: Measurement of $\mathrm{OH}$ and $\mathrm{HO}_{2}$ in the troposphere, Chem. Rev., 103, 5163-5196, 2003.

Houweling, S., Dentener, F., and Lelieveld, J.: The impact of nonmethane hydrocarbon compounds on tropospheric photochemistry, J. Geophys. Res., 103, 10 673-10 696, 1998.

Jöckel, P., Tost, H., Pozzer, A., Brühl, C., Buchholz, J., Ganzeveld, 
L., Hoor, P., Kerkweg, A., Lawrence, M. G., Sander, R., Steil, B., Stiller, G., Tanarhte, M., Taraborrelli, D., Aardenne, J. V., and Lelieveld, J.: The atmospheric chemistry general circulation model ECHAM5/MESSy1: consistent simulation of ozone from the surface to the mesosphere, Atmos. Chem. Phys., 6, 50675104, 2006,

http://www.atmos-chem-phys.net/6/5067/2006/.

Karl, T., Guenther, A., Yokelson, R. J., Greenberg, J., Potosnak, M., Blake, D. R., and Artaxo, P.: The tropical forest and fire emissions experiment: Emission, chemistry, and transport of biogenic volatile organic compounds in the lower atmosphere over Amazonia, J. Geophys. Res., 112, D18302, doi:10.1029/2007JD008539, 2007.

Kerkweg, A., Sander, R., Tost, H., and Jöckel, P.: Technical note: Implementation of prescribed (OFFLEM), calculated (ONLEM), and pseudo-emissions (TNUDGE) of chemical species in the Modular Earth Submodel System (MESSy), Atmos. Chem. Phys., 6, 3603-3609, 2006,

http://www.atmos-chem-phys.net/6/3603/2006/.

Krol, M. and Lelieveld, J.: Can the variability in tropospheric $\mathrm{OH}$ be deduced from measurements of 1,1,1trichloroethane (methyl chloroform)?, J. Geophys. Res., 108, 4125, doi:10.1029/2002JD002423, 2003.

Krol, M. C., Molemaker, M. J., and de Arellano, J. V. G.: Effects of turbulence and heterogeneous emissions on photochemically active species in the convective boundary layer, J. Geophys. Res., 105, 6871-6884, 2000.

Kubistin, D., Harder, H., Martinez, M., Rudolf, M., Sander, R., Bozem, H., Eerdekens, G., Fischer, H., Gurk, C., Klüpfel, T., Königsstedt, R., Parchatka, U., Schiller, C., Stickler, A., Taraborrelli, D., Williams, J., and Lelieveld, J.: Hydroxyl radicals in the tropical troposphere over the Suriname rain forest: Comparison of measurements with the box model MECCA, Atmos. Chem. Phys. Discuss., accepted, 2008.

Kuhn, U., Andreae, M. O., Ammann, C., Araújo, A. C., Brancaleoni, E., Ciccioli, P., Dindorf, T., Frattoni, M., Gatti, L. V., Ganzeveld, L., Kruijt, B., Lelieveld, J., Lloyd, J., Meixner, F. X., Nobre, A. D., Pöschl, U., Spirig, C., Stefani, P., Thielmann, A., Valentini, R., and Kesselmeier, J.: Isoprene and monoterpene fluxes from Central Amazonian rainforest inferred from towerbased and airborne measurements, and implications on the atmospheric chemistry and the local carbon budget, Atmos. Chem. Phys., 7, 2855-2879, 2007,

http://www.atmos-chem-phys.net/7/2855/2007/.

Kurpius, M. R. and Goldstein, A. H.: Gas-phase chemistry dominates $\mathrm{O}_{3}$ loss to a forest, implying a source of aerosols and hydroxyl radicals to the atmosphere, Geophys. Res. Lett., 30, 1371, doi:10.1029/2002GL016785, 2003.

Lawrence, M. G., Rasch, P. J., von Kuhlmann, R., Williams, J., Fischer, H., de Reus, M., Lelieveld, J., Crutzen, P. J., Schultz, M., Stier, P., Huntrieser, H., Heland, J., Stohl, A., Forster, C., Elbern, H., Jakobs, H., and Dickerson, R. R.: Global chemical weather forecasts for field campaign planning: predictions and observations of large-scale features during MINOS, CONTRACE, and INDOEX, Atmos. Chem. Phys., 3, 267-289, 2003, http://www.atmos-chem-phys.net/3/267/2003/

Lelieveld, J., Dentener, F. J., Peters, W., and Krol, M. C.: On the role of hydroxyl radicals in the self-cleansing capacity of the troposphere, Atmos. Chem. Phys., 4, 2337-2344, 2004, http://www.atmos-chem-phys.net/4/2337/2004/.

Lelieveld, J., Butler, T. M., Crowley, J. N., Dillon, T. J., Fischer, H., Ganzeveld, L., Harder, H., Lawrence, M. G., Martinez, M., Taraborrelli, D., and Williams, J.: Atmospheric oxidation capacity sustained by a tropical forest, Nature, 452, 737-740, 2008.

Martinez, M., Harder, H., Kubistin, D., Rudolf, M., Bozem, H., Fischer, H., Gurk, C., Königsstedt, R., Klüpfel, T., Parchatka, U., Schiller, C., Stickler, A., Williams, J., and Lelieveld, J.: Hydroxyl radicals in the tropical troposphere over the Suriname rain forest: Airborne measurements Atmos. Chem. Phys. Discuss., accepted, 2008.

Pöschl, U., von Kuhlmann, R., Poisson, N., and Crutzen, P. J.: Development and intercomparison of condensed isoprene oxidation mechanisms for global atmospheric modeling, J. Atmos. Chem., 37, 29-52, 2000.

Pozzer, A., Jöckel, P., Tost, H., Sander, R., Ganzeveld, L., Kerkweg, A., and Lelieveld, J.: Simulating organic species with the global atmospheric chemistry general circulation model ECHAM5/MESSy1: a comparison of model results with observations, Atmos. Chem. Phys., 7, 2527-2550, 2007, http://www.atmos-chem-phys.net/7/2527/2007/.

Prinn, R. G., Huang, J., Weiss, R. F., Cunnold, D. M., Fraser, P. J., Simmonds, P. G., McCulloch, A., Harth, C., Reimann, S., Salameh, P., O’Doherty, S., Wang, R. H. J., Porter, L. W., Miller, B. R., and Krummel, P. B.: Evidence for variability of atmospheric hydroxyl radicals over the past quarter century, Geophys. Res. Lett., 32, L07809, doi:10.1029/2004GL022228, 2005.

Ren, X., Brune, W. H., Oliger, A., Metcalf, A. R., Simpas, J. B., Shirley, T., Schwab, J. J., Bai, C., Roychowdhury, U., Li, Y., Cai, C., Demerjian, K. L., He, Y., Zhou, X., Gao, H., and Hou, J.: $\mathrm{OH}, \mathrm{HO}_{2}$, and $\mathrm{OH}$ reactivity during the PMTACS-NY Whiteface Mountain 2002 campaign: Observations and model comparison, J. Geophys. Res., 111, D10S03, doi:10.1029/2005JD006126, 2006.

Roeckner, E., Bäuml, G., Bonaventura, L., Brokopf, R., Esch, M., Giorgetta, M., Hagemann, S., Kirchner, I., Kornbluch, L., Manzini, E., Rhodin, A., Schlese, U., Schulzweida, U., and Tompkins, A.: The atmospheric general circulation model ECHAM5: part 1, model description, Tech. Rep. 349, Max Planck Institut für Meteorologie, Hamburg, 2003.

Sander, R., Kerkweg, A., Jöckel, P., and Lelieveld, J.: Technical note: The new comprehensive atmospheric chemistry module MECCA, Atmos. Chem. Phys., 5, 445-450, 2005, http://www.atmos-chem-phys.net/5/445/2005/.

Sander, S. P., Friedl, R. R., Golden, D. M., Kurylo, M. J., Moortgat, G. K., Keller-Rudek, H., Wine, P. H., Ravishankara, A. R., Kolb, C. E., Molina, M. J., Finlayson-Pitts, B. J., Huie, R. E., and Orkin, V. L.: Chemical kinetics and photochemical data for use in atmospheric studies, Evaluation Number 15, JPL Publication 06-2, Jet Propulsion Laboratory, Pasadena, 2006.

Saunders, S. M., Jenkin, M. E., Derwent, R. G., and Pilling, M. J.: Protocol for the development of the Master Chemical Mechanism, MCM v3 (Part A): tropospheric degradation of nonaromatic volatile organic compounds, Atmos. Chem. Phys., 3, 161-180, 2003, http://www.atmos-chem-phys.net/3/161/2003/.

Shirley, T. R., Brune, W. H., Ren, X., Mao, J., Lesher, R., Cardenas, B., Volkamer, R., Molina, L. T., Molina, M. J., Lamb, B., Velasco, E., Jobson, T., and Alexander, M.: Atmospheric oxi- 
dation in the Mexico City Metropolitan Area (MCMA) during April 2003, Atmos. Chem. Phys., 6, 2753-2765, 2006, http://www.atmos-chem-phys.net/6/2753/2006/.

Spivakovsky, C. M., Wofsy, S. C., and Prather, M. J.: A numericalmethod for parameterization of atmospheric chemistry - computation of tropospheric OH, J. Geophys. Res., 95, 18 433-18 439, 1990.

Spivakovsky, C. M., Logan, J. A., Montzka, S. A., Balkansky, Y. J., Foreman-Fowler, M., Jones, D. B. A., Horowitz, L. W., Fusco, A. C., Brenninkmeijer, C. A. M., Prather, M. J., Wofsey, S. C., and McElroy, M. B.: Three-dimensional climatological distribution of tropospheric $\mathrm{OH}$ : Update and evaluation, J. Geophys. Res., 105, 8931-8980, 2000.

Stevenson, D. S., Dentener, F. J., Schultz, M. G., Ellingsen, K., van Noije, T. P. C., Wild, O., Zeng, G., Amann, M., Atherton, C. S., Bell, N., Bergmann, D. J., Bey, I., Butler, T., Cofala, J., Collins, W. J., Derwent, R. G., Doherty, R. M., Drevet, J., Eskes, H. J., Fiore, A. M., Gauss, M., Hauglustaine, D. A., Horowitz, L. W., Isaksen, I. S. A., Krol, M. C., Lamarque, J. F., Lawrence, M. G., Montanaro, V., Müller, J. F., Pitari, G., Prather, M. J., Pyle, J. A., Rast, S., Rodriguez, J. M., Sanderson, M. G., Savage, N. H., Shindell, D. T., Strahan, S. E., Sudo, K., and Szopa, S.: Multi-model ensemble simulations of present-day and near-future tropospheric ozone, J. Geophys. Res., 111, D08301, doi:10.1029/2005JD006338, 2006.

Stickler, A., Fischer, H., Bozem, H., Gurk, C., Schiller, C., Martinez-Harder, M., Kubistin, D., Harder, H., Williams, J., Eerdekens, G., Yassaa, N., Ganzeveld, L., Sander, R., and Lelieveld, J.: Chemistry, transport and dry deposition of trace gases in the boundary layer over the tropical Atlantic Ocean and the Guyanas during the GABRIEL field campaign, Atmos. Chem. Phys., 7, 3933-3956, 2007, http://www.atmos-chem-phys.net/7/3933/2007/.

Taraborrelli, D., Lawrence, M. G., Butler, T. M., Sander, R., and Lelieveld, J.: Mainz Isoprene Mechanism 2 (MIM2): an isoprene oxidation mechanism for regional and global atmospheric modelling, Atmos. Chem. Phys. Discuss., 8, 14033-14085, 2008, http://www.atmos-chem-phys-discuss.net/8/14033/2008/.
Tan, D., Faloona, I., Simpas, J. B., Brune, W., Shepson, P. B., Couch, T. L., Summer, A. L., Carroll, M. A., Thornberry, T., Apel, E., Riemer, D., and Stockwell, W.: $\mathrm{HO}_{\mathrm{x}}$ budgets in a deciduous forest: Results from the PROPHET summer 1998 campaign, J. Geophys. Res., 106, 24 407-24 427, 2001.

Thornton, J. A., Wooldridge, P. J., Cohen, R. C., Martinez, M., Harder, H., Brune, W. H., Williams, E. J., Roberts, J. M., Fehsenfeld, F. C., Hall, S. R., Shetter, R. E., Wert, B. P., and Fried, A.: Ozone production rates as a function of $\mathrm{NO}_{\mathrm{x}}$ abundances and $\mathrm{HO}_{\mathrm{x}}$ production rates in the Nashville urban plume, J. Geophys. Res., 107, 4146, doi:10.1029/2001JD000932, 2002.

Tost, H., Jöckel, P., and Lelieveld, J.: Influence of different convection parameterisations in a GCM, Atmos. Chem. Phys., 6, 54755493, 2006 a.

Tost, H., Jöckel, P. J., Kerkweg, A., Sander, R., and Lelieveld, J.: Technical note: A new comprehensive SCAVenging submodel for global atmospheric chemistry modelling, Atmos. Chem. Phys., 6, 565-574, 2006b.

Tost, H., Jöckel, P. J., and Lelieveld, J.: Lightning and convection parameterisations - uncertainties in global modelling, Atmos. Chem. Phys., 7, 4553-4568, 2007,

http://www.atmos-chem-phys.net/7/4553/2007/.

Verver, G. H. L., van Dop, H., and Holtslag, A. A. M.: Turbulent mixing and the chemical breakdown of isoprene in the atmospheric boundary layer, J. Geophys. Res., 105, 3983-4002, 2000.

von Kuhlmann, R., Lawrence, M. G., and Crutzen, P. J.: A model for studies of tropospheric ozone and nonmethane hydrocarbons: Model evaluation of ozone-related species, J. Geophys. Res., 108, 4729, doi:10.1029/2002JD003348, 2003.

von Kuhlmann, R., Lawrence, M. G., Pöschl, U., and Crutzen, P. J.: Sensitivities in global scale modeling of isoprene, Atmos. Chem. Phys., 4, 1-17, 2004,

http://www.atmos-chem-phys.net/4/1/2004/.

Williams, J., Gros, V., Bonsang, B., and Kazan, V.: HO cycle in 1997 and 1998 over the southern Indian Ocean derived from CO, radon, and hydrocarbon measurements made at Amsterdam Island, J. Geophys. Res., 106, 12 719-12 725, 2001. 